\title{
El contencioso de la unidad de mercado
}

\author{
Juan Alfonso Santamaría Pastor \\ Catedrático de Derecho Administrativo \\ Gómez-Acebo \& Pombo, Abogados
}

\begin{abstract}
SUMARIO. I. LOS PRESUPUESTOS. II. RASGOS GENERALES DEL SISTEMA. III. LOS PROGEDIMIENTOS CONTENGIOSOS ORDINARIOS. A) La iniciación de los procedimientos. B) La legitimación. C) Los recursos previos. IV. EL PROCEDIMIENTO CONTENCIOSO ESPECIAL. A) Caracteres generales. B) Cuestiones y trámites previos. 1. La competencia jurisdiccional. 2. La legitimación de la GNMC. 3. La personación de interesados como intervinientes. C) La interposición del recurso especial. 1. El requerimiento del artículo 44.2. Los plazos. 3. Los requisitos del escrito de interposición. D) Las medidas cautelares. 1. La solicitud y su alcance. 2. El carácter automático de la suspensión. 3. El momento de producción de la suspensión. 4. Inexigibilidad de caución. 5. El levantamiento de la suspensión. E) Diligencias preliminares del proceso. 1. Reclamación del expediente administrativo. 2. Emplazamiento de los interesados. 3. La acumulación y sus problemas. F) Fase de alegaciones y prueba. G) Terminación del proceso. 1. La sentencia y su contenido. 2. La forma de la sentencia y las sentencias in voce. 3 . La extensión de efectos de la sentencia. V. UNA VALORAGIÓN DE CONJUNTO.
\end{abstract}

\section{RESUMEN:}

Este trabajo pretende exponer la regulación de los procedimientos contencioso-administrativos regulados por la reciente Ley 20/2013, a través de los cuales se trata de establecer vías procesales para asegurar las libertades de establecimiento y circulación de bienes y servicios en el territorio nacional, superando las disfunciones creadas por las regulaciones dispares establecidas por las Comunidades Autónomas. Se trata de unos procedimientos judiciales complejos, el principal de los cuales se confía a la iniciativa exclusiva de la Comisión Nacional de los Mercados y la Competencia, pero en el que se permite la intervención de los operadores económicos privados que hayan sido lesionados por medidas discriminatorias establecidas por las Administraciones territoriales. 


\section{PALABRAS GLAVE:}

Proceso contencioso-administrativo; unidad de mercado; libertades de establecimiento y circulación; Comisión Nacional de los Mercados y la Competencia.

\section{ABSTRACT:}

This work aims to expose the regulation of contentious-administrative procedures regulated by the recent Act 20/2013, through which it is establishing procedural ways to ensure freedoms of establishment and movement of goods and services in the national territory, overcoming dysfunctions created by the disparate regulations set by the Autonomous Communities. These are complex legal proceedings, the principal of which is entrusted to the sole initiative of the National Commission on Financial Markets and Competition, but in which the intervention of private economic operators who have been injured by discriminatory measures established by the territorial Government is permitted.

\section{KEYWORDS:}

Contentious-administrative process; market unit; freedom of establishment and movement; National Commission on Financial Markets and Competition.

\section{LOS PRESUPUESTOS}

Hay muchas formas a través de las cuales el estamento político puede hacer notar la importancia que quiere darse a la protección de determinados valores; o que comparte la preocupación que determinados estratos de la sociedad comienzan a sentir respecto de problemas emergentes, mostrando una actitud decidida a hacerles frente.

Es desalentador comprobar que la respuesta mayoritaria que dicho estamento ha sido capaz de ofrecer a la sociedad española, en los últimos treinta años, ha sido la judicialización de los conflictos y la criminalización de conductas que comenzaban a inquietar a algunos sectores sociales. La primera línea de acción explorada consistió en el gesto de crear unidades especializadas dentro de la Fiscalía General del Estado y de la Policía Nacional; la segunda, en la incorporación masiva al Código Penal de un alto número de conductas antes consideradas lícitas o, a lo sumo, merecedoras de un mero reproche colectivo o de sanciones administrativas. Y en la última década comienza a aparecer, como novísimo trending topic, el establecimiento de nuevas modalidades procesales y la ampliación de la legitimación para emprenderlas.

Este último método de dramatización de las políticas públicas es una inclina- 
ción común a un amplio espectro de las fuerzas políticas: una tendencia transversal, compartida axiomáticamente por las ideologías de izquierda y de derecha. Aunque no sean los únicos casos, deben recordarse aquí las acusadas semejanzas de planteamiento que, en cuanto a los instrumentos de actuación, se advierten entre la Ley Orgánica 3/2007, de 22 de marzo, para la igualdad efectiva de mujeres y hombres, de una parte, y la reciente Ley 20/2013, de Garantía de la Unidad de Mercado; una y otra han optado por judicializar concretos tipos de conflictos (eso sí, de naturaleza muy diversa, y cada uno de ellos muy apegado a la sensibilidad respectiva de los partidos políticos que promovieron ambas leyes), y por cursar inv(c)itaciones explícitas a colectivos y entidades de todo tipo para iniciar los respectivos tipos de procesos.

La eficacia práctica de esta "línea de trabajo" suscita todo tipo de explicables escepticismos; pero de lo que no cabe duda es de que está produciendo el alumbramiento de una nueva forma de entender el proceso contencioso, que ya no solo va a ser el instrumento de defensa de los ciudadanos frente a los excesos del poder público, sino también un escenario de confrontación entre agrupaciones sociales y entes públicos, en el que unas y otros, cual caballeros medievales, harán exhibición de sus fuerzas; confiando la confirmación de sus más radicales prejuicios ideológicos no ya al juicio de Dios, como antaño, sino a la decisión irrevocable de un órgano cuyo acierto se da por seguro exclusivamente en base a su independencia y a su imparcialidad. Y todo ello ante la perpleja mirada de una ciudadanía ignorante de los beneficios que todas estas justas caballerescas aportarán a su seguridad y a su bienestar.

\section{RASGOS GENERALES DEL SISTEMA}

La Ley 20/2013, de Garantía de la Unidad de Mercado (en adelante, LUM), es un texto normativo particularmente ambicioso. Dejando a un lado los principios enunciados en sus artículos 3 a 8 (sobre cuya eficacia práctica nada podemos añadir a la desconfianza que dimana de la práctica en la aplicación de normas similares), los artículos 16 a 20, que constituyen el núcleo duro de la Ley, son de unas pretensiones realmente espectaculares; y, de aplicarse efectivamente, supondrán una auténtica revolución en el conjunto formado por los vigentes ordenamientos autonómicos.

$\mathrm{Al}$ servicio de estos preceptos, que se estudian detalladamente en otras partes de este libro, la Ley establece un complejo sistema de mecanismos de garantía. Algunos de ellos (los regulados en los Capítulos III y VI, artículos 10 a 15 y 22 a 25) son de naturaleza puramente interadministrativa; y, junto a éstos se implanta un nuevo cuadro de procedimientos administrativos y judiciales. Estos últimos son el objeto de la presente colaboración, sin perjuicio de las referencias que ine- 
vitablemente habrán de hacerse a las vías administrativas previas reguladas en los artículos 26 y 27 , en cuanto condicionan el acceso a los recursos ordinarios, distinto del ahora regido por los nuevos artículos 127 bis, ter y quáter de la Ley reguladora de la Jurisdicción Contencioso-Administrativa (en adelante, LJCA).

Sin entrar por el momento en el detalle de la iniciación, trámite y resolución del recurso contencioso-administrativo especial que la LUM ha creado, el nuevo sistema de recursos puede describirse sintéticamente en unos pocos puntos.

A) La LUM parte de la apertura de dos tipos de procedimientos judiciales alternativos:

1) primero, el que pueden emprender los operadores económicos que estimen "que se han vulnerado sus derechos o intereses legítimos por alguna disposición de carácter general, acto, actuación, inactividad o vía de hecho que pueda ser incompatible con la libertad de establecimiento o de circulación, en los términos previstos en esta Ley" (artículo 26.1); se trata de un procedimiento contenciosoadministrativo ordinario, que puede emprenderse por dichos operadores dejando a un lado los mecanismos específicos de reclamación previa y de posterior impugnación regulados en los artículos 26 y 27 de la Ley y en los artículos 127 bis a quáter de la LJCA;

2) y segundo, un procedimiento contencioso especial, que puede ser precedido por las vías previas reguladas en los artículos 26 y 27 de la LUM, y cuya incoación corresponde en exclusiva a la Comisión Nacional de los Mercados y la Competencia (en adelante, GNMC). A este procedimiento se refieren los puntos que siguen.

B) La vía previa a la incoación de este procedimiento contencioso especial se articula en dos fases: una primera, ante el nuevo Consejo para la Unidad de Mercado, que podríamos llamar de intento de conciliación (artículo 26); la segunda, ante la CNMC, instándole a adoptar la decisión de interponer el recurso contencioso-administrativo especial.

C) Este procedimiento contencioso especial puede dirigirse contra las mismas actuaciones que son susceptibles de cualquier recurso contencioso-administrativo, conforme a los artículos 25 a 30 de la LJCA: así lo disponen el apartado 1 del artículo 127 bis de la LJCA y el artículo 26.1 de la LUM.

D) El nuevo procedimiento especial se dirige a una finalidad específica y exclusiva, que resulta del rótulo del propio Capítulo y que se traduce en una limitación de las infracciones del ordenamiento jurídico que pueden invocarse en el 
mismo: las cuales no podrán ser otras que las que supongan una vulneración de las libertades de establecimiento y circulación, tal como aparecen protegidas por la LUM.

E) La tramitación y resolución de este proceso especial se encomienda a un único órgano jurisdiccional: la Sala de lo Contencioso-Administrativo de la Audiencia Nacional, según dispone la nueva letra h) del art. 11.1 de la LJCA (también añadida por la LUM), con entera independencia de la naturaleza estatal, autonómica o local de los entes u órganos autores de las actuaciones o disposiciones generales que se impugnen.

F) Se trata, por lo demás, de un procedimiento abreviado en el que se prescinde del trámite de vista o conclusiones y al que se dota de una especial celeridad: los plazos se reducen y, salvo el de interposición por la GNMG, que es de dos meses, son semejantes a los previstos en el procedimiento para la protección de los derechos fundamentales (arts. 114 a 122 bis LJCA). Al igual, también, de lo que sucede en este recurso especial, se reconoce carácter preferente a la tramitación de los recursos para la garantía de la unidad de mercado.

G) Y, por último, su regulación se encuentra fragmentada, no agotándose en los nuevos artículos que se incorporan a la LJCA: en concreto, la legitimación para la interposición del recurso no se regula mediante la modificación del art. 19 LJCA, sino que se contiene en los arts. 26 y 27 de la LUM.

Todos estos rasgos hacen necesario un análisis de estos tipos de procesos, a lo largo de todas sus fases. Esta es la finalidad del presente trabajo, que pretende desentrañar los múltiples interrogantes que esta novedosa regulación suscita, así como señalar sus desgraciadamente numerosos defectos y contradicciones, que sería deseable fueran salvados en una ulterior reforma legislativa.

Huelga decir que esta exposición tiene un acusado carácter de provisionalidad: se ha finalizado cuando se cumplen solo veinte días desde la publicación de la Ley 20/2013 en el Boletín Oficial del Estado. En estas condiciones, es obvio advertir que muchas de las opiniones que aquí se vierten habrán de ser rectificadas o matizadas cuando la doctrina (y, sobre todo, la jurisprudencia; que tardará) proceda a un análisis más detenido del contenido de la Ley; pero, aun con estos riesgos, me ha parecido oportuno ofrecer a los letrados que hayan de intervenir en los procesos, y quizá a los jueces que hayan de decidirlos, una primera orientación en el laberinto procesal que la Ley de Garantía de la Unidad de Mercado ha construido. 


\section{LOS PROCEDIMIENTOS CONTENGIOSOS ORDINARIOS}

El objeto principal de la LUM, en el plano formal, se concreta en el establecimiento del procedimiento contencioso especial, reservado a su utilización por la CNMC; pero no cierra la puerta a los recursos que puedan querer interponer los operadores económicos ${ }^{1}$, prescindiendo de la iniciativa de la CNMC, contra las actuaciones administrativas contrarias a la libertad de mercado.

Dichos recursos son, obviamente, los ordinarios regulados en el Título IV de la LJCA (no, desde luego, el previsto en los artículos 127 bis, ter y quáter); y, pese a su más que sumaria regulación en la LUM (o quizá precisamente por dicha sumariedad), plantean numerosas dudas interpretativas.

\section{A) La iniciación de los procedimientos}

Dichos procedimientos pueden incoarse en tres hipótesis u ocasiones.

1. La LUM permite, en primer lugar, que cualquier operador económico pueda interponer un recurso contencioso-administrativo contra cualquier actuación que lesione sus derechos o intereses, dejando a un lado por completo las vías administrativas previas que la propia Ley regula: así se deduce claramente de lo establecido en el artículo 26.3 de la misma.

2. El operador que se considere lesionado por alguna de estas actuaciones puede, en segundo lugar, utilizar el procedimiento de conciliación o arreglo previo regulado en el artículo 26 de la LUM, dirigiendo su reclamación a la Secretaría del Consejo para la Unidad de Mercado (artículo 26.1). La resolución que en dicho procedimiento dicte la que el artículo 26 llama "autoridad competente afectada" habrá de notificarse al operador reclamante por la mencionada Secretaría (artículo 26.7).

a) La Ley no dice con claridad qué vía puede tomar el operador en el caso de que la resolución dictada por la autoridad competente afectada no le resulte satisfactoria: es evidente que puede reproducir su reclamación ante la CNMC en un plazo de cinco días (artículo 26.8); pero parece igualmente notorio que puede también apartarse de dicha vía de reclamación y emprender un procedimiento contencioso ordinario contra dicha resolución. Así debe entenderse la disposición del artículo 26.9, aunque esté referida a un supuesto diverso.

\footnotetext{
${ }^{1} \mathrm{O}$ las organizaciones representativas que menciona el artículo 26.2: por razones de abreviación, nos referimos a continuación solo a los operadores. Véase, no obstante, lo que se dice en el epígrafe referido a la legitimación.
} 
En efecto: dicho apartado 9 prevé la hipótesis de que el operador reclamante pretenda alegar contra la medida impugnada motivos de legalidad distintos de la vulneración de las libertades de establecimiento y circulación (p. ej., defectos de forma). Dado que el procedimiento contencioso especial no puede basarse en más que en los motivos indicados, se le permite emprender una impugnación paralela y parcial mediante la interposición de un recurso contencioso ordinario, que podrá basarse en motivos ajenos a la infracción de la unidad de mercado, sin perjuicio de continuar su reclamación por dichos motivos ante la CNMC. Y, como en el momento en que se le notifique la resolución de la "autoridad competente afectada" habrá ya expirado el plazo para interponer recurso administrativo o contencioso, la LUM prevé la rehabilitación de dicho plazo, disponiendo que "el plazo para su interposición se iniciará cuando se produzca la inadmisión o eventual desestimación de la reclamación por la autoridad competente".

En consecuencia, si se permite al operador reclamante un apartamiento parcial de la vía de reclamación prevista en los artículos 26 y 27 de la LUM para iniciar un proceso contencioso, no hay razón para prohibirle un apartamiento total, si cree que la vía especial de reclamación no tiene posibilidades razonables de prosperar.

b) Así pues, las posibilidades que se ofrecen al operador reclamante que acude a la vía de reclamación ante el Consejo para la Unidad de Mercado son tres: i) puede abandonar (momentáneamente, como en seguida veremos) la vía del recurso contencioso autónomo, y replantear su reclamación ante la GNMC, como prevé el artículo 27; ii) puede, también, efectuar dicho replanteamiento ante la CNMC y emprender por su cuenta y riesgo un recurso contencioso autónomo contra la medida lesiva de la unidad de mercado, si pretendiera utilizar motivos impugnatorios distintos de la infracción de dicha unidad, y iii) puede también abandonar esta vía de reclamación, interponiendo recurso ordinario contra la medida.

c) Pero esto no agota todas las hipótesis posibles. En concreto: ¿puede el reclamante continuar con la reclamación ante la GNMC y, al tiempo, interponer un recurso contencioso ordinario contra la medida y resolución que han sido objeto de la reclamación? Hablamos de un recurso contencioso plenario, esto es, no limitado a la impugnación en base a motivos distintos del de lesión de la unidad de mercado (que es el supuesto previsto en el artículo 26.9), sino que se apoye también en este último.

En mi opinión, esta posibilidad debe ser descartada, por razones elementales de economía procesal. No cabe negar al operador que planteó su reclamación al Consejo para la Unidad de Mercado a prescindir de los sucesivos pasos de dicha 
vía y litigar separadamente, con plenitud de fundamentos. Pero no tiene lógica permitirle adoptar esta vía si, al tiempo, replantea su reclamación ante la CNMC, por la sencilla razón de que, como veremos en el siguiente punto 3, puede volver a apartarse de la intermediación de la Comisión y acudir al procedimiento contencioso ordinario cuando ésta rechace o inadmita su reclamación. Si opta por el replanteamiento de su queja ante la Comisión, parece razonable que haya de esperar a la resolución de ésta para tomar el camino del recurso contencioso ordinario.

3. La tercera vía de apartamiento que se ofrece al operador surge, precisamente, con ocasión de la reclamación que puede replantear ante la CNMC, si la decisión adoptada por la "autoridad competente afectada" no le resulta satisfactoria.

La reclamación tiene por objeto, evidentemente, instar a la CNMC a que incoe el procedimiento contencioso especial; la cual puede considerar improcedente tal incoación, a la vista de la reclamación y del informe que sobre la misma deberá remitirle la Secretaría del Consejo para la Unidad de Mercado; o, por el contrario, estimarla y decidir emprender el procedimiento especial, notificando su decisión, en ambos casos, al operador reclamante. Y, en tal caso, vuelven a abrirse diversas posibilidades.

a) Si la decisión de la CNMC rechaza (por razones de fondo) o inadmite (por falta de legitimación, o por extemporaneidad) la reclamación del operador, parece evidente que éste podrá interponer recurso contencioso ordinario contra la medida lesiva de la unidad de mercado y contra la resolución desestimatoria de la autoridad competente afectada ( $\mathrm{y}$, quizá, también contra el rechazo de la CNMC, si éste entra en el fondo y declara que la medida no vulnera la unidad de mercado). Así se deduce del artículo 27.5 de la LUM, según el cual "el plazo para interponer un recurso contencioso-administrativo ordinario por parte de los operadores que hayan presentado su solicitud a la Comisión Nacional de los Mercados y la Competencia quedará suspendido hasta que ésta le comunique su decisión" (artículo 27.5).

b) Pero la decisión de la CNMC puede estimar la reclamación, decidiendo emprender por sí el proceso especial de los artículos 127 bis a quáter. ¿Qué puede hacer, en tal caso, el operador reclamante? Las vías posibles, en este caso, se triplican:

i) Primera posibilidad: el operador prescinde de interponer cualquier recurso contencioso paralelo, confiando en que la actuación procesal de la GNMC le resuelva su problema. En tal caso, podrá personarse en el proceso especial que la CNMC incoe, en la singular forma prevista en el artículo 127 ter, apartado 7, a 
la que más adelante nos referiremos. Pero esta personación es puramente facultativa, por lo que también podrá abstenerse de actuar en el proceso, esperando su decisión final como un tercero interesado.

ii) Segunda posibilidad: el operador tiene en cartera, en contra de la medida lesiva de la unidad de mercado, motivos impugnatorios distintos de los referidos, como prevé el artículo 26.9 de la LUM. Por analogía con lo establecido en este último precepto, parece que el citado operador podrá iniciar un proceso contencioso paralelo para hacer valer tales motivos (de los que no podría hacer uso en su personación en el proceso especial); a la misma conclusión se llega a la vista de lo dispuesto por el artículo 27.5, que transcribimos párrafos atrás. Y, en tal supuesto, podrá también personarse en el proceso especial que incoe la GNMC, en la forma que antes mencionamos.

iii) Tercera posibilidad: el operador no confia plenamente en la solidez de la impugnación que pueda llevar a cabo la CNMC por la vía del proceso especial. En tal caso, se plantea el interrogante de si el mismo puede emprender un proceso ordinario contra la medida lesiva de la unidad de mercado; un proceso pleno, sin limitación en cuanto a los motivos impugnatorios a esgrimir (esto es, la infracción de la LUM, además de los restantes que considere procedentes); y ello sin perjuicio de, además, personarse en el recurso especial que la CNMC interponga.

Esta última posibilidad nos parece más dudosa. Desde luego, no puede negarse al operador reclamante la posibilidad de apartarse, en este momento, de la reclamación emprendida al amparo de los artículos 26 y 27 y de iniciar un proceso autónomo por su cuenta. Pero no parece admisible que, al tiempo, pretenda intervenir como recurrente en el proceso especial que incoe a su instancia la GNMC, alegando simultáneamente la infracción de la unidad de mercado en ambos procedimientos: esta posibilidad estaría excluida por la prohibición de litispendencia (artículo 69.d) de la LJCA), ya que concurrirían entre ambas impugnaciones las tres identidades clásicas definidas por la doctrina jurisprudencial: identidad subjetiva de las partes y de la calidad en que actúan, misma causa de pedir, causa petendi, o fundamento de la pretensión y 3) igual petitum o conclusión. No se olvide que, en su personación en el proceso especial, el operador asume la posición de recurrente, la misma que ostentaría en el proceso ordinario que pudiera incoar.

No es preciso ponderar en exceso la extrema complejidad de supuestos que suscita esta posibilidad de interposición de recursos paralelos. Y esta complejidad se acrecienta si tomamos en consideración otros factores. 


\section{B) La legitimación}

El primero de ellos, quién está legalmente habilitado para interponer recursos contenciosos (ordinarios, los únicos a los que nos referimos en este epígrafe III) contra las actuaciones de los poderes públicos que lesionen el principio de unidad de mercado.

Este interrogante surge con ocasión de la referencia contenida en el artículo 26.2 de la LUM: "Las organizaciones representativas de los operadores económicos, incluidas las Cámaras Oficiales de Comercio y las asociaciones profesionales, podrán acudir al procedimiento previsto en el apartado anterior en defensa de los intereses colectivos que representan". No hablamos en este epígrafe de la participación de dichas organizaciones en las vías previas y en el proceso especial que puede incoar la CNMC, sino de si las mismas se hallan legitimadas para interponer recurso contencioso ordinario contra las actuaciones que consideren lesivas de la unidad de mercado.

La respuesta debe ser, desde luego, afirmativa. Aunque la LUM solo reconozca dicha legitimación (en vía administrativa) para su intervención en las vías previas y en el proceso especial, la misma deriva de lo establecido en el artículo 19.1.b) de la LJCA, que legitima ante el orden jurisdiccional contencioso-administrativo a "las corporaciones, asociaciones, sindicatos y grupos y entidades a que se refiere el artículo 18 que resulten afectados o estén legalmente habilitados para la defensa de los derechos e intereses legítimos colectivos". Obsérvese, por otra parte, que esta enumeración es sensiblemente más amplia que la que contiene el artículo 26.2 de la LUM; lo que supone que estos recursos contenciosos (ordinarios) en defensa de la unidad de mercado podrán ser interpuestos también por las entidades y organizaciones que el artículo 26.2 no menciona (en concreto, los sindicatos y los grupos de afectados).

Si las medidas a impugnar lesionan los intereses colectivos que cada una de estas organizaciones y entidades tengan atribuidos por ley o por sus normas estatutarias, parece indiscutible que podrán interponer los recursos contenciosos ordinarios que estimen oportunos para la defensa de dichos intereses. Ni siquiera podría plantearse aquí la cuestión de si, para ostentar tal legitimación, se requiere de una habilitación legislativa específica (además de la que deriva del artículo 19.1.b), como el mismo precepto parece exigir). Creemos que tal habilitación específica (caso de estimarse necesaria, a lo que la jurisprudencia ha respondido implícitamente en sentido negativo) se encontraría en los artículos 26.2 y concordantes de la propia LUM. 
Y, por supuesto, dichas posibilidades impugnatorias podrían ejercitarse en los mismos términos y ocasiones que la LUM reconoce a los operadores económicos, apartándose total o parcialmente de su intervención en las vías previas ante el Consejo para la Unidad de Mercado y ante la CNMC, en la forma y supuestos que analizamos en el anterior epígrafe A).

\section{C) Los recursos previos}

En el caso de interposición, por los operadores económicos y por las entidades corporativas y asociativas mencionadas en el artículo 26.2 de la LUM, de recursos contenciosos ordinarios contra las actuaciones públicas lesivas de la unidad de mercado, ¿qué vías de recurso administrativo previo deben seguirse? Aunque las mismas podrían deducirse de la exposición hecha en el anterior epígrafe A), conviene recordarlas brevemente, por su complejidad.

1. Ninguna duda digna de mención plantean los supuestos en los que un operador económico, una corporación o asociación, o cualquier otro interesado decida impugnar una actuación pública de esta naturaleza al margen de las vías previas y del procedimiento especial que la LUM regula, ya que nos hallamos ante el régimen común de impugnación de actos y disposiciones administrativas:

a) No podrá interponerse recurso administrativo alguno si la actuación pública a impugnar tiene la naturaleza de disposición de carácter general, por prohibirlo el artículo 107.3 de la Ley 30/1992; debiendo ser directamente impugnada ante la jurisdicción contencioso-administrativa.

b) Si la actuación a impugnar consiste en un acto administrativo que no pone fin a la vía administrativa, deberá interponerse el correspondiente recurso de alzada (o la reclamación económico-administrativa que proceda) contra dicho acto (artículo 114.1 de la Ley 30/1992).

c) $\mathrm{Si}$, por el contrario, el acto pone fin a la vía administrativa, deberá ser directamente impugnado ante la jurisdicción contenciosa; pudiendo interponerse previamente, con carácter potestativo, recurso de reposición (artículo 116.1 de la Ley 30/1992).

d) Si el objeto de la impugnación fuera la inactividad administrativa (en las dos modalidades previstas en los apartados 1 y 2 del artículo 29 de la LJCA), el recurso en vía contenciosa deberá ir precedido de una reclamación a la Administración inactiva, pudiendo interponerse dicho recurso una vez transcurridos tres meses o un mes, respectivamente, desde la presentación de dicha reclamación. Pese a que el artículo citado emplea la expresión "pueden reclamar", la ju- 
risprudencia ha considerado tal reclamación como obligatoria (últimamente, la STS de 2 de abril de 2013, Casación 5720/2011).

e) Por fin, si lo que tratara de impugnarse fuera una actuación en vía de hecho, el recurso contencioso podrá ir precedido de un requerimiento (en este caso, meramente potestativo) que deberá ser contestado en el plazo de diez días (artículo 30 de la LJCA).

2. Los problemas comienzan a suscitarse cuando alguna de las personas físicas o jurídicas que se mencionaron en el anterior epígrafe 1 hubieran optado por hacer uso de las vías previas reguladas en los artículos 26 y 27 de la LUM y, posteriormente, se apartaran de ellas en las formas que examinamos en el epígrafe A).

a) La primera posibilidad de apartamiento se produce, como ya vimos, cuando, tras la reclamación formulada ante la Secretaría del Consejo para la Unidad de Mercado, la autoridad competente afectada la desestima expresa o tácitamente. Dicha autoridad puede ser de aquéllas cuyos actos ponen fin a la vía administrativa, o no; pero esta diferencia no es relevante, ya que el artículo 26.7 de la LUM dispone que "cuando se trate de actuaciones administrativas que no agoten la vía administrativa, la resolución de la autoridad competente debidamente notificada pondrá fin a dicha vía”. Contra dicha resolución, en consecuencia, solo cabrá interponer directamente recurso contencioso, que podrá ser previamente recurrido en reposición, siempre de forma potestativa.

b) Y la segunda ocasión de apartarse del procedimiento especial acaece cuando, como también vimos, la CNMC rechaza o inadmite su queja (art. 27.3 de la LUM); también, cuando su resolución no satisface al operador reclamante, o cuando éste pretende hacer uso de motivos de impugnación distintos al de la lesión de la unidad de mercado. En este caso, ¿iserá necesario interponer recurso de alzada si la medida contra la que se formuló la reclamación no pone fin a la vía administrativa?

La LUM guarda silencio sobre este extremo, limitándose a decir que "el plazo para interponer un recurso contencioso-administrativo ordinario por parte de los operadores que hayan presentado su solicitud a la Comisión Nacional de los Mercados y la Competencia quedará suspendido hasta que ésta le comunique su decisión" (artículo 27.5). Pero si esta regla se une a la contenida en el artículo 26.7, que dispone que la resolución de la autoridad competente afectada pondrá fin en todo caso a la vía administrativa, puede concluirse con seguridad que no cabrá interponer recurso de alzada, porque no tendría sentido que la resolución de la autoridad competente afectada pone fin a la vía administrativa en la primera fase de este procedimiento administrativo especial, pero no en la segunda. 
La acertada prevención de que el plazo para interponer recurso contencioso quedará en suspenso hasta tanto la CNMC comunique al reclamante su decisión revela la convicción implícita del legislador de que la vía administrativa de recurso ha quedado plenamente agotada y sustituida por la de la reclamación, en sus dos fases, por lo que no cabe ya otra alternativa que acudir directamente ante el juez contencioso.

No obstante, la inagotable inventiva de los reclamantes obliga a plantear un último interrogante: rechazada o inadmitida la queja por la GNMG, ¿puede el reclamante, antes de interponer el recurso contencioso, recurrir en reposición ante la autoridad competente afectada? Creemos que no puede negarse esta posibilidad. El agotamiento de las reclamaciones ante el Consejo para la Unidad de Mercado, primero, y ante la CNMC, después, no tiene otro efecto, para el operador, que la sustitución de la vía administrativa de recurso jerárquico por aquellas otras; tanto el rechazo de la reclamación por la autoridad competente afectada como, posteriormente, por la GNMC, tienen como único efecto la finalización de la vía administrativa. Y si un particular puede interponer siempre recurso de reposición potestativo contra las decisiones que ponen fin a la dicha vía (artículo 116.1 de la Ley 30/1992), no existe razón para negarle esta facultad en el caso que examinamos. Y, en tal caso, la prevención que hace el artículo 27.5 de la LUM en el sentido de que el plazo para interponer recurso contencioso solo se iniciará en la fecha de la notificación de la resolución desestimatoria o de inadmisión de la GNMC, habrá de entenderse referida al plazo para interponer el recurso de reposición aludido.

\section{EL PROGEDIMIENTO GONTENGIOSO ESPEGIAL}

\section{A) Caracteres generales}

La regulación del proceso contencioso especial se abordó por la LUM mediante la adición al Título V de la LJCA de un nuevo Capítulo IV (comprensivo de los artículos 127 bis, ter y quáter), así como añadiendo una nueva letra h) al artículo 11.1 (sobre las competencias de la Sala de lo Contencioso-Administrativo de la Audiencia Nacional) y reformando ligeramente el artículo 110.1, también de la LJCA. De modo asistemático, sin embargo, algunas cuestiones claramente procesales se han mantenido por el legislador en el articulado de la LUM, como son las relativas a la legitimación para emprender este proceso especial (artículo 27) y las vías administrativas previas al mismo (artículos 26 y 27).

1. En términos generales, la regulación que se hace del proceso es seriamente deficiente: se trata de una regulación fragmentaria, hecha a golpes de brocha gorda, en la que únicamente se establecen las normas que difieren respecto de las 
establecidas para el proceso contencioso ordinario (cuya regulación se declara supletoria: artículo 127 ter, apartado 10) y en la que quedan en la penumbra múltiples cuestiones sustanciales.

2. El rasgo más característico de esta regulación es, desde luego, la celeridad que pretende imprimirse al proceso, que se manifiesta en un drástico acortamiento de los plazos para la realización de los diferentes trámites: cinco días para remitir el expediente administrativo en lugar de veinte; diez días, y no veinte, para formalizar la demanda y la contestación; veinte, y no treinta, para el período de prueba; y cinco días, en lugar de diez $(\dot{i}$ ?) para dictar sentencia; todo ello unido al carácter preferente que se otorga a la tramitación del recurso (artículo 127 ter, apartado 9). Y la perla: la posibilidad de dictar la sentencia in voce (artículo 127 ter, apartado 6).

Todo este apresuramiento carece de sentido y utilidad: en pocas ocasiones podría decirse de una regulación, con mayor fundamento, aquello de que los autores del texto confundieron el tocino con la velocidad. Es probable que esta artificial prisa se justifique en la pretensión de obtener una sentencia en el menor plazo posible, habida cuenta del régimen de suspensión automática que prevé el artículo 127 quáter (y de la lógica paralización que ello supone de la actuación administrativa impugnada). Pero resulta dificilmente explicable que el redactor del texto (que, sin duda, debe haber sido alguna persona con una cierta experiencia procesal) haya olvidado que las demoras en el pronunciamiento de una sentencia no se deben tanto a los plazos de tramitación de un recurso cuanto al dilatado período que media entre la declaración del proceso como concluso y dicho pronunciamiento, dada la carga de trabajo que pesa sobre todos los órganos jurisdiccionales; y que este período no se acorta de modo voluntarista con una mera declaración de tramitación preferente, de la que gozan otros muchos procesos.

Y contra esta gratuita celeridad juega, además, el sistema de recursos jurisdiccionales. No se olvide que las sentencias que dicte la Audiencia Nacional serán recurribles ante la Sala Tercera del Tribunal Supremo; y que el recurso de casación será admisible con mucha frecuencia si se tiene en cuenta que la mayor parte de los recursos será de cuantía indeterminada (artículo 86.2.b) de la LJCA), o que versarán sobre la nulidad de las disposiciones que impongan barreras a la unidad de mercado (artículo 86.3). ¿Para qué, entonces, tanta prisa en tramitar el proceso de instancia si, a su término, el asunto habrá de colocarse pacientemente en una larga lista de espera para su fallo, y después ser sometida su sentencia a un recurso de casación?

3. Pero, además, la celeridad es una característica manifiestamente inadecuada para debatir y resolver los conflictos que se tramitarán en este proceso espe- 
cial. Por mucho esfuerzo que la LUM haya desplegado para concretarlo (que lo ha hecho), el concepto de unidad de mercado es, hoy por hoy, de una notable indeterminación, de límites fluctuantes y difusos en un sistema político basado en la autonomía recíproca de las Administraciones territoriales, al que es inherente un cierto grado de desigualdad en las regulaciones respectivas. Los debates procesales acerca de si una determinada medida lesiona o no las libertades de establecimiento y circulación habrán de ser de una notable sutileza y con un importante componente económico (como también sucede en los asuntos de defensa de la competencia); y pretender despacharlos en plazos fugaces de alegación (y sin conclusiones) no puede llevar más que a la chapuza, forzando a la Audiencia Nacional a dictar sentencias de motivación insuficiente, por escasez de elementos de juicio.

\section{B) Cuestiones y trámites previos}

\section{La competencia jurisdiccional}

Como ya antes señalamos, la LUM añadió al artículo 11.1 de la LJCA una nueva letra h), en la que se atribuye a la Sala de lo Contencioso-Administrativo de la Audiencia Nacional la competencia para conocer "de los recursos interpuestos por la Comisión Nacional de los Mercados y de la Competencia en defensa de la unidad de mercado".

Esta decisión competencial supone una ruptura de los principios que inspiran el régimen de distribución contenido en los artículos 8 a 12 de la LJCA, que asignan las competencias primariamente en base al órgano que hubiera realizado o dictado la actuación administrativa impugnada. Supone, por tanto, que la Sala de la Audiencia Nacional conocerá de todos estos recursos, con independencia de que la actuación recurrida provenga de una entidad local, de una comunidad autónoma, de la Administración del Estado o de algún ente instrumental de cualquiera de ellas.

Tal ruptura merece un juicio inequívocamente positivo; porque si el valor que pretende asegurar este tipo de procesos es la unidad de mercado, nada sería más desaconsejable que confiar su resolución a órganos jurisdiccionales diversos, cuyas decisiones, potencialmente dispares, no podrían ser reconducidas a criterios unitarios utilizando el peculiar sistema de recursos contra sentencias que rige entre nosotros.

Este mecanismo carece, sin embargo, de una pieza clave para asegurar la completa unidad de criterio. El legislador olvidó en este punto, quizá, que, junto 
a los recursos en defensa de la unidad de mercado que interponga la GNMC, se entablarán otros muchos ordinarios por los diferentes operadores económicos y corporaciones (los que hemos examinado en el epígrafe III); recursos que, en defecto de cualquier regla de atribución competencial en la LUM, habrán de ser tramitados y fallados por los Juzgados de lo Contencioso-Administrativo, los Juzgados Centrales, las Salas de los Tribunales Superiores de Justicia y, por qué no, también por la Sala Tercera del Tribunal Supremo. Y olvidó también que algunos de estos recursos podrán dirigirse contra la misma actuación administrativa que, al tiempo, esté siendo objeto de impugnación por la CNMC ante la $\mathrm{Au}-$ diencia Nacional, pudiendo dar lugar a sentencias radicalmente contradictorias: unas, declarando que las actuaciones respectivas no vulneran la unidad de mercado, y otras, anulándolas por lesionar el referido precepto constitucional.

Si la intención del legislador fue asegurar por la vía judicial la unidad de mercado, esta carencia constituirá el talón de Aquiles de todo el sistema; ello solo podría evitarse atribuyendo a la Audiencia Nacional todos los recursos que, interpuestos por la CNMC o por cualquier otro sujeto, impugnen una actuación administrativa por infracción del principio de unidad de mercado; imponiendo a los demás jueces y tribunales la obligación de declinar el conocimiento de estos asuntos a favor de la Audiencia Nacional (el mecanismo de acumulación previsto en el apartado 8 del artículo 127 ter es manifiestamente insuficiente, como más adelante razonaremos).

\section{La legitimación de la GNMC}

a) Ya señalamos anteriormente que la LUM atribuye la legitimación para incoar estos procesos especiales a la GNMC: legitimación que tiene carácter exclusivo y excluyente de cualquier otra persona o entidad. Aunque tal exclusividad no aparece claramente expresada en el artículo 27.1 de la $\mathrm{LUM}^{2}$, este rasgo se deduce de la redacción de los arts. 127 bis, 127 ter y 127 quáter, que únicamente mencionan como recurrente (o, en el último caso, como solicitante de la medida cautelar de suspensión) a la Comisión Nacional de los Mercados y de la Competencia.

\footnotetext{
2 "La Comisión Nacional de los Mercados y la Competencia está legitimada para la interposición de recurso contencioso-administrativo frente a cualquier disposición de carácter general, acto, actuación, inactividad o vía de hecho que se considere contraria, en los términos previstos en esta Ley, a la libertad de establecimiento o de circulación procedente de cualquier autoridad competente, de acuerdo con el procedimiento previsto en el Capítulo IV del Título V de la Ley 29/1998, de 13 de julio, Reguladora de la Jurisdicción Contencioso-Administrativa".
} 
Esta regla constituye una singularidad absoluta: salvo error por mi parte, en ningún caso la ley legitima para interponer un tipo de recursos a una única persona jurídica. No es, sin embargo, la primera vez que el legislador otorga legitimación a entidades públicas, en plural, para interponer recursos ${ }^{3}$, lo cual, como señalé al comienzo de esta colaboración, marca una inesperada tendencia hacia el activismo administrativo en el uso de los instrumentos judiciales.

b) ¿Por qué legitimar a un organismo estatal para interponer estos recursos, y por qué precisamente a la CNMC? Es posible que esta decisión responda a un intento de exhibir una actitud proactiva del Estado en la defensa de la unidad de mercado, no limitándose a esperar pasivamente a que sean los operadores económicos privados quienes protagonicen dicha defensa; y es probable que legitimar a la CNMC tuviera como objeto dar una apariencia de objetividad y tecnicismo a las impugnaciones que hubieran de hacerse de actos y normas de comunidades autónomas, como emprendidas por un organismo público independiente del Gobierno de la Nación.

Ello, de ser cierto, sería a mi juicio tan defendible como equivocado, porque olvida que la unidad de mercado es un objetivo que no solo debe ser medido de acuerdo con los criterios de la ciencia económica o del Derecho; es, sobre todo, un valor de naturaleza política; y se corre el riesgo de que un organismo fuertemente técnico como la GNMC tienda a evaluar las denuncias que se le hagan de lesiones a la unidad de mercado con criterios de ortodoxia económica o jurídica, no políticos. Pero este es, quizá, el precio que ha de pagarse cuando la garantía de dicha unidad se pone, en última instancia, en manos del aparato judicial, en vez de asumirse y defenderse con los instrumentos propios del Gobierno.

c) La decisión de la GNMG de incoar el proceso, o de no hacerlo, es incoercible. La LUM establece una legitimación universal (llamada impropiamente acción pública: ver más adelante) para solicitar de la Comisión que interponga el

\footnotetext{
${ }^{3}$ Me refiero, en primer lugar, a los recursos en defensa del derecho de igualdad de trato entre mujeres y hombres, que pueden interponer, cuando los afectados sean una pluralidad de personas indeterminada o de difícil determinación, "los organismos públicos con competencia en la materia": artículo 19.1.i, párrafo segundo, de la LJCA, letra que fue añadida por la Ley Orgánica 3/2007, de 22 de marzo, para la igualdad efectiva de mujeres y hombres. No hay aquí, sin embargo, exclusividad alguna, ya que dichos recursos pueden también ser incoados por los sindicatos más representativos y las asociaciones de ámbito estatal cuyo fin primordial sea la igualdad entre mujeres y hombres. La legitimación de la CNMC tampoco es una novedad, ya que el artículo 5.4 de su Ley de creación (Ley 3/2013, de 4 de junio) legitima también a ésta para impugnar ante la jurisdicción contencioso-administrativa los actos de las Administraciones Públicas sujetos al Derecho administrativo y las disposiciones generales de rango inferior a la ley "de los que se deriven obstáculos al mantenimiento de una competencia efectiva en los mercados".
} 
recurso; pero tales peticiones no le vinculan en modo alguno. La GNMC deberá valorar "en el plazo de cinco días si procede la interposición de recurso contencioso-administrativo, informando al operador de su decisión" (artículo 27.3). Nos parece evidente que tal decisión no es susceptible de recurso; máxime cuando una negativa a interponer el recurso no deja indefensos a los solicitantes, los cuales podrán, acto seguido, interponer recurso contencioso-administrativo ordinario contra la actuación presuntamente lesiva de la unidad de mercado, cuyo plazo no se iniciará hasta tanto la Comisión no le comunique su decisión negativa (artículo 27.5).

Por lo demás, no podemos dejar de aludir a la notoria imprecisión de que la LUM hace gala al referirse a las personas que pueden formular a la CNMC la solicitud de que recurra la medida que les afecta: el artículo 26 se refiere reiteradamente a "los operadores económicos"; también habilita para elevar estas solicitudes a sus organizaciones representativas, así como a las Cámaras Oficiales de Comercio y las Asociaciones Profesionales (apartados 2 y 8); pero el artículo 27.2 vuelve a referirse solo a los operadores económicos.

Y, para mayor confusión, la disposición adicional quinta establece que "será pública la acción para exigir ante los órganos administrativos y, a través de la Comisión Nacional de los Mercados y la Competencia, ante los Tribunales el cumplimiento de lo establecido en esta Ley y en las disposiciones que se dicten para su desarrollo y ejecución, para la defensa de la unidad de mercado"; norma ésta que engloba y hace innecesarios los reconocimientos de legitimación que mencionamos en el párrafo anterior. Y es doblemente superfluo el párrafo segundo de dicha disposición adicional que, como antes vimos, dice que "en particular, se reconoce la legitimación de las corporaciones, asociaciones y grupos de afectados para ejercer el derecho de petición a que se refiere el artículo 27 de esta Ley". Parece evidente que si el párrafo primero establece una acción pública, la legitimación específica a las entidades que menciona en su párrafo segundo sobra por completo.

Tampoco podemos dejar de formular un reproche al incorrecto empleo de la expresión "acción pública". Una acción de este tipo que solo habilita para solicitar a la CNMC que interponga un recurso contencioso, pero que no legitima para interponerlo a quien formula la solicitud, no puede recibir esta denominación, porque se trata de una simple denuncia o de un supuesto de ejercicio del derecho constitucional de petición. No es malicioso suponer que el uso que de esta fórmula hace la LUM no tiene más efecto que el puramente propagandístico, desde el momento en que el establecimiento de auténticas acciones populares solo tiene lugar en los casos en los que el legislador pretende magnificar la relevancia extrema de los valores que intentan protegerse con ellas. 


\section{La personación de interesados como intervinientes}

Una novedad no menos notable en el plano de los sujetos intervinientes en el proceso se encuentra en el apartado 7 del artículo 127 ter, según el cual, "durante la tramitación del procedimiento, podrá solicitar su intervención, como parte recurrente, cualquier operador económico que tuviere interés directo en la anulación del acto, actuación o disposición impugnada y no la hubiera recurrido de forma independiente".

El precepto no puede dejar de producir sorpresa, al ser la primera vez en la historia del contencioso español en la que se permite la participación sobrevenida en el proceso, como parte recurrente, de un sujeto distinto del que interpuso el recurso contencioso-administrativo (posibilidad que la jurisprudencia ha excluido en una doctrina invariable). Parece claro que, con esta novedad, el Gobierno ha pretendido controlar estrictamente la iniciación del proceso, impidiendo que lo planteen los reclamantes que lo hubieren solicitado a la CNMC. Varias cuestiones deben resaltarse respecto de esta nueva figura.

a) Primera, quiénes pueden ser intervinientes. La lectura de corrido del texto de los artículos 26 y 27 de la LUM y, después, de los nuevos artículos 127 bis, ter y quáter de la LJCA podría hacer suponer que tendrían derecho a personarse en el proceso especial como intervinientes quienes hubieran ejercitado la reclamación previa ante el Consejo para la Unidad de Mercado y formulado la petición de impugnar a la CNMC. Pero el artículo 127 ter, 7 habla, más genéricamente, de "cualquier operador económico que tuviere interés directo en la anulación del acto, actuación o disposición impugnada y no la hubiera recurrido de forma independiente"; y parece evidente que lo normal será que quienes soliciten intervenir en el proceso sean quienes hayan solicitado a la CNMC que interponga el recurso; pero el precepto permite también la intervención de cualquier otro operador económico provisto de un interés directo (siempre que no hubiera emprendido un recurso contencioso diverso contra la misma actuación que se impugne en éste), aunque no hubiera seguido los trámites de los artículos 26 y 27 de la LUM.

¿Solo los operadores económicos? Dejando a un lado la fuerte ambigüedad de este concepto, nos parece que los redactores de la LUM olvidaron que el artículo 26 de la misma permite formular reclamaciones y peticiones al Consejo para la Unidad de Mercado y a la CNMC también a "las organizaciones representativas de los operadores económicos, incluidas las Cámaras Oficiales de Comercio y las asociaciones profesionales" (apartados 2 y 8). Este olvido fue salvado, no obstante, por el párrafo segundo de la disposición adicional quinta de la LUM, que claramente establece que "se reconoce la legitimación de las corpora- 
ciones, asociaciones y grupos de afectados para ejercer el derecho de petición a que se refiere el artículo 27 de esta Ley y para personarse en el procedimiento para la garantía de la unidad de mercado regulado en el Capítulo IV del Título V de la Ley 29/1998, de 13 de julio, Reguladora de la Jurisdicción ContenciosoAdministrativa".

b) Segunda, cuál sea la naturaleza procesal del tercero interviniente. De la regulación que hace del mismo el apartado 7 del artículo 127 ter se deduce con nitidez que la función que este precepto le asigna no es la propia de un mero coadyuvante de la CNMC. El texto de la norma puntualiza que su intervención es "como parte recurrente" de pleno derecho, lo cual supone dos cosas: i) primera, que "podrá defender las pretensiones formuladas [por la CNMG] o las que el propio interviniente formule", esto es, pretensiones propias y distintas de la de anulación de la actuación impugnada, como, por ejemplo, las de "el resarcimiento de los daños y perjuicios, incluido el lucro cesante" que menciona el segundo párrafo del artículo 127 ter, 6; ii) y segunda, que "podrá utilizar los recursos que procedan contra las resoluciones que estime perjudiciales para su interés, aunque las consienta la Comisión Nacional de los Mercados y la Competencia o las demás partes personadas".

Esta posición como parte recurrente auténtica supone, también, que el proceso no finalizará si la CNMC desistiera de la impugnación emprendida, ya que el artículo 74.5 de la LJCA dispone que "si fueren varios los recurrentes, el procedimiento continuará respecto de aquellos que no hubieren desistido". Con lo cual puede llegarse a la situación, un tanto paradójica, de que un proceso que solo puede iniciar la CNMC finalice con un único recurrente distinto de la Comisión, que sea quien lleve a término la protección jurisdiccional de la unidad de mercado.

c) Y tercera: la facultad que se atribuye al interviniente de ejercitar pretensiones propias supone la posibilidad de utilizar en su defensa una línea argumental diversa de la que haya utilizado previamente la CNMC como recurrente principal.

Es problemático, sin embargo, si el interviniente podrá emplear motivos de impugnación distintos de la lesión de la unidad de mercado. Tal posibilidad parece vedada por el artículo 26.9 de la LUM, antes mencionado, que obliga a los reclamantes a esgrimir dichos motivos en un proceso ordinario, independiente del que estamos analizando; pero el apartado 6 del artículo 127 ter parece mantener una postura más flexible al decir que "la sentencia estimará el recurso cuando la disposición, la actuación o el acto incurrieran en cualquier infracción del ordenamiento jurídico que afecte a la libertad de establecimiento o de circula- 
ción, incluida la desviación de poder"; este precepto supone que la fundamentación de este recurso no habrá de basarse exclusivamente en la infracción de los preceptos que, de una u otra forma, protejan la unidad de mercado, sino que podrá alegarse (y acogerse por la sentencia) cualquier otra infracción del ordenamiento, siempre que tal infracción ocasione una lesión a dicha unidad. Es, en suma, lo mismo que el artículo 121.2 de la LJCA establece respecto del proceso especial de protección de los derechos fundamentales de la persona.

\section{C) La interposición del recurso especial}

El artículo 127 bis se refiere de modo muy sumario a la incoación del proceso especial, lo que obliga a completar estas someras alusiones con las normas de los artículos 44 a 48 de la LJCA. Y ello plantea algunas cuestiones de muy distinta dificultad.

1. La primera de ellas, si cabe la formulación del requerimiento potestativo que regula el artículo 44. La cuestión no es ociosa, dado que estos recursos especiales son, por su propia naturaleza, litigios entre Administraciones Públicas.

En nuestra opinión, esta pregunta debe responderse negativamente en el caso de que la CNMC actúe a instancia de alguna de las personas legitimadas para solicitarle la interposición del recurso: en tal caso, la función que desempeña el requerimiento previo está cubierta por el trámite regulado en el artículo 26 de la LUM, que permite a la Administración autora de la actuación considerada como lesiva de la unidad de mercado pronunciarse sobre la reclamación formulada por un particular. No tendría sentido, y sería contrario al principio de celeridad que inspira la regulación de los artículos 127 bis, ter y quáter, permitir la anteposición de un requerimiento que tendría carácter puramente redundante.

Por el contrario, la cuestión debe ser respondida afirmativamente en los casos en los que la CNMC actúe de oficio, como prevé el artículo 27.2 de la LUM. La Comisión, en efecto, puede interponer el recurso especial sin que su actuación haya sido instada por nadie, en base a su propia información. En tales supuestos, no habiendo precedido a la interposición ningún trámite de arreglo amistoso similar al regulado en el artículo 26 de la LUM, el requerimiento previsto en el artículo 44 de la LJCA puede resultar no solo legalmente procedente, sino incluso oportuno.

2. El plazo para la interposición del recurso por parte de la CNMG viene regulado en el apartado 2 del artículo 127 bis, siendo su cómputo distinto según que la interposición del recurso se acuerde de oficio por la Comisión o a instancia de alguna persona. 
a) En el primer caso, la LUM remite a los plazos y forma de cómputo establecidos en los apartados 1 a 3 del artículo 46 de la LJCA. No plantea ninguna dificultad el cómputo del plazo cuando lo que vaya a impugnarse sea una disposición de carácter general (siendo el dies a quo el de su publicación oficial); pero la regla del artículo 46.1 no será aplicable en el caso de que el recurso vaya a dirigirse contra un acto administrativo, ya que no parece probable que la Administración autora de la actuación lo notifique a la CNMC. En tal supuesto, habrá de estarse a la fecha en la que la Comisión declare haber tenido conocimiento del acto.

Por lo demás, y aunque no serán frecuentes los supuestos en que se vulnere la libertad de mercado mediante una actuación en vía de hecho, en los casos en que pueda producirse nos parece que el plazo de diez o veinte días para interponer que establece el artículo 46.3 es extremadamente reducido para una Administración de las dimensiones y complejidad de la GNMC. Quizá hubiera sido preferible establecer una excepción a lo dispuesto en dicho precepto, y fijar un plazo único de dos meses para el recurso contra todo tipo de actuaciones administrativas.

b) Cuando la interposición del recurso se realice aceptando la solicitud de una persona, "el plazo de dos meses se computará desde la [fecha de] presentación de la solicitud ante la Comisión Nacional de los Mercados y la Competencia", dice el apartado 2 del artículo 127 bis. La interpretación de la regla no ofrece dificultad alguna; solo cabe advertir de la desproporción que existe entre este plazo y el fijado en el artículo 27.3 de la LUM, según el cual la CNMC dispone de solo cinco días para adoptar una decisión sobre la solicitud que haya formulado un ciudadano (que es la tarea que puede consumir un mayor lapso de tiempo), y de dos meses para preparar un escrito de interposición que no exige más de media hora de trabajo.

3. Ni la LUM ni la LJCA aluden a los requisitos del escrito de interposición ni a sus documentos anejos, que lógicamente habrán de ser los mismos que prevé, para el procedimiento ordinario, el artículo 45, apartados 1 y 2, de la LJCA. Su comentario no corresponde al objeto de este trabajo; pero sí debe llamarse la atención acerca de la necesidad de que el representante o defensor procesal de la CNMC aporte el coloquialmente llamado "acuerdo corporativo" que menciona el apartado 1.d) del artículo 45; esto es, el acuerdo adoptado por el órgano competente de la Comisión en orden a la interposición del recurso; en la actualidad, dicho órgano es el Consejo de la Comisión de conformidad con lo establecido en el art. 8.2.f) de su Estatuto Orgánico (Real Decreto 657/2013, de 30 de agosto), que le atribuye la función de "acordar, a propuesta del Secretario del Consejo o de otras autoridades competentes de la Comisión, la interposición de recursos". 
Por supuesto, cabe la posibilidad de que la incoación del recurso se realice no con un sencillo escrito de interposición, sino directamente mediante demanda. El artículo 46.5 de la LJCA admite esta modalidad de iniciación en los procesos dirigidos "contra una disposición general, acto, inactividad o vía de hecho en que no existan terceros interesados"; y ésta es una hipótesis que no será rara que se dé en estos recursos especiales, muchos de los cuales se emprenderán contra disposiciones generales de las distintas Administraciones públicas y desde una perspectiva abstracta y general, esto es, por su potencialidad para causar lesiones a las libertades de establecimiento y circulación, antes incluso de que hayan podido ser objeto de aplicación a sus destinatarios privados; pleitos en los que, por tanto, no existirán aún terceros interesados.

\section{D) Las medidas cautelares}

El régimen de medidas cautelares aplicable a este proceso especial, contenido en el artículo 127 quáter, es su rasgo más notable y singular. Se trata de un régimen similar al previsto en los artículos 128 y siguientes de la LJCA, en el que destaca la singularidad de la suspensión de la disposición, acto o resolución impugnados, a la que se da carácter automático; una técnica directamente inspirada en el artículo 161.2 CE para el recurso de inconstitucionalidad interpuesto por el Presidente del Gobierno contra las disposiciones y resoluciones adoptadas por los órganos de las Comunidades Autónomas.

\section{La solicitud y su alcance}

Las partes recurrentes pueden solicitar cualquier medida cautelar en el curso del proceso (artículo 127 quáter, 1), de acuerdo con el régimen general de numerus apertus o medidas innominadas.

La solicitud de medidas cautelares puede ser hecha por cualquiera de las partes recurrentes. El artículo 127 quáter, 1 menciona solo a la CNMC; pero es obvio que el tercero interviniente, en su condición plena de recurrente, puede también solicitarlas, incluida la suspensión de la ejecución o aplicación de la disposición o acto impugnados.

\section{El carácter automático de la suspensión}

Con excepción de la suspensión solicitada por la CNMG (que es, como decíamos, automática), la tramitación y otorgamiento de las restantes medidas cautelares, tanto si son solicitadas por la Comisión como por los terceros intervinientes, se sujeta a las normas generales de la LJCA (artículo 127 quáter, 3); lo que significa que la suspensión pedida por el tercero interviniente (si no lo hu- 
biera hecho ya la GNMC, claro está) habrá de tramitarse y otorgarse por el órgano jurisdiccional, en su caso, con sujeción a dichas normas generales.

En cuanto a la suspensión pedida por la GNMC, debemos recordar que, en el régimen general establecido por la LJCA, las medidas cautelares se adoptan siempre mediante una decisión del órgano jurisdiccional ante el que se interpone el recurso ( $y$, salvo en el supuesto de las medidas urgentes previstas en el artículo 135, previa audiencia de las demás partes procesales). En cambio, de acuerdo con el apartado 2 de este artículo, la suspensión se produce automáticamente, una vez solicitada por la CNMC, y "una vez admitido el recurso": esto es, en el momento en que el Secretario judicial dicta la resolución de admisión correspondiente (art. 45.2 LJCA).

La suspensión, pues, se produce ex lege, sin necesidad de que ninguna resolución del órgano jurisdiccional lo declare o acuerde; y, lo que no es menos importante, tiene lugar inaudita altera parte, esto es, sin que para ello deba oírse a las partes demandadas (lo que, por otro lado, no sería posible en este momento inicial del proceso, en el que ni siquiera ha llegado noticia formal de su existencia a la Administración demandada).

\section{El momento de producción de la suspensión}

Pero es dudoso que, como parece decir el artículo 127 quáter, la suspensión surta efectos con la mera resolución de admisión del recurso. Es preciso, como mínimo, que dicha resolución sea notificada a la Administración demandada para que ésta pueda cumplirla; y dicha notificación se producirá, normalmente, junto con la resolución de admisión y la reclamación del expediente.

Y aun esto no será suficiente cuando lo que se impugne en el recurso sea una disposición de carácter general. Téngase en cuenta que el artículo 134.2 de la LJCA (recordemos: supletoriamente aplicable a este proceso especial) dispone que "la suspensión de la vigencia de disposiciones de carácter general será publicada con arreglo a lo dispuesto en el artículo 107.2"; precepto que dispone que "el Secretario del órgano judicial ordenará su publicación en diario oficial en el plazo de diez días a contar desde la firmeza de la sentencia”. Y estas normas han de ser completadas, a su vez, con lo dispuesto en el artículo 72.2, también de la LJCA, establece que "las sentencias firmes que anulen una disposición general tendrán efectos generales desde el día en que sea publicado su fallo y preceptos anulados en el mismo periódico oficial en que lo hubiera sido la disposición anulada".

Todo ello supone que la Administración demandada no podrá hacer aplicación de la norma suspendida a partir de la fecha de recepción de la comunica- 
ción del Secretario judicial; pero que la suspensión no tendrá efectos frente a terceros sino a partir de la fecha en la que la resolución del Secretario se inserte en el diario oficial correspondiente.

\section{Inexigibilidad de caución}

En el régimen general de medidas cautelares, la Administración que hubiere realizado la actuación recurrida, y las restantes partes demandadas, pueden solicitar al propio órgano jurisdiccional que adoptó una medida cautelar la indemnización de los daños que ésta les hubiere causado, una vez que la medida pierda su eficacia (art. 133.3 de la LJCA); y, para asegurar el pago de dicha indemnización, el apartado 1 del mismo artículo habilita al órgano jurisdiccional para exigir la prestación de caución o garantía suficiente para responder de aquellos daños.

Sin embargo, el artículo 127 quáter, 2, exime a la CNMC de la obligación de afianzar el abono de las indemnizaciones antes aludidas. Pero de la exención de esta obligación (que, por otra parte, es un privilegio general de todos los entes públicos: respecto del Estado, véase el art. 12, párrafo primero de la Ley 52/1997, de 27 de noviembre, de Asistencia Jurídica al Estado e Instituciones Públicas) no puede deducirse, en modo alguno, una paralela exención del deber de indemnizar los daños que la suspensión automática pudiera producir, que es una obligación autónoma, independiente de la de garantizar su abono. La excepción del deber de afianzar que este art. 127 quáter establece no conlleva la exención del deber de indemnizar.

\section{El levantamiento de la suspensión}

En el régimen general de medidas cautelares, la suspensión que se hubiera acordado puede ser objeto de revocación, a lo largo del proceso, "si cambiaran las circunstancias en virtud de las cuales se hubieran adoptado" (art. 132.1). En este procedimiento especial, en cambio, el legislador prefirió continuar aplicando el modelo previsto por el art. 161.2 CE, atribuyendo al tribunal la facultad de levantar la suspensión, automáticamente producida, en un plazo de tres meses. Las características de este trámite son las siguientes:

a) El levantamiento de la suspensión solo podrá acordarse a solicitud de la Administración demandada: lo dice con toda claridad el precepto al disponer que "la Administración cuya actuación se haya recurrido podrá solicitar el levantamiento de la suspensión...". No cabe, por tanto, el levantamiento de oficio de la suspensión.

b) La solicitud debe formularse "en el plazo de tres meses desde su adopción". La expresión no es enteramente concluyente, pudiendo suscitarse la duda de si la 
petición ha de formularse dentro de los tres meses siguientes a la fecha de producción automática de la suspensión (esto es, desde la fecha de la resolución del tribunal admitiendo a trámite el recurso), o si solo puede formularse una vez expirado dicho plazo.

El paralelismo que esta norma guarda con el art. 161.2 CE (que dice que "el Tribunal, en su caso, deberá ratificarla o levantarla en un plazo no superior a cinco meses") aconseja optar por la primera de las interpretaciones apuntadas; lo que significa, a efectos prácticos, que el levantamiento podrá solicitarse de modo inmediato (esto es, incluso el día siguiente a aquél en que la Administración demandada tenga conocimiento de la suspensión producida).

c) La solicitud ha de motivarse, necesariamente, mediante justificación razonada de que del mantenimiento de la suspensión "pudiera seguirse una perturbación grave de los intereses generales o de tercero que el tribunal ponderará en forma circunstanciada" (fórmula ésta que es, literalmente, la que el art. 130.2 LJCA utiliza para referirse a los motivos de denegación de una medida cautelar).

Ello no supone que los intereses a ponderar por el tribunal hayan de ser, exclusivamente, los propios que la Administración demandada persiguió al realizar la actuación que se impugna en el proceso. El párrafo segundo de este apartado 2 alude a "los intereses en conflicto", pues la suspensión también persigue proteger intereses distintos de los de la Administración demandada: los propios de la necesidad de proteger la unidad de mercado. La decisión judicial sobre el levantamiento de la suspensión deberá ponderar, por tanto, todos estos intereses contrapuestos, inclinándose por levantarla cuando los lesionados propios de la Administración demandada sean de una intensidad superior a los que la impugnación pretende proteger.

d) Antes de resolver sobre la solicitud de levantamiento de la suspensión, el tribunal deberá oír, por plazo de diez días, a la CNMC en defensa de aquélla. Naturalmente, si en el proceso hubieran comparecido otras personas, tanto a título de partes demandadas como demandantes (al amparo en este caso de lo previsto en el art. 127 ter, 7), entendemos que deberán ser igualmente oídas, por el mismo plazo.

\section{E) Diligencias preliminares del proceso}

\section{Reclamación del expediente administrativo}

El artículo 127 ter, apartado 1, dispone que "en el mismo día de la interposición del recurso [...] o en el siguiente, el Secretario judicial requerirá con carác- 
ter urgente al órgano administrativo correspondiente, $[\ldots]$ para que en el plazo máximo de cinco días a contar desde la recepción del requerimiento remita el expediente acompañado de los informes y datos que se soliciten en el recurso, con apercibimiento de cuanto se establece en el artículo 48".

Pese a su aparente simplicidad y semejanza con lo dispuesto en el artículo 48.1, esta norma plantea algunas cuestiones.

a) En primer lugar, la relativa al momento de reclamación del expediente. Según el precepto, ha de producirse el mismo día en que la CNMC interponga el recurso o, como máximo, en el siguiente. Esta disposición responde, sin duda, al criterio de celeridad extrema que el legislador quiso imprimir a este proceso; pero es tan voluntarista como imposible de cumplir en la mayor parte de los casos.

En efecto: para poder reclamar el expediente, el Secretario Judicial debe, de acuerdo con el artículo 45.3 de la LJCA, examinar previamente el escrito de interposición y sus documentos anejos para cerciorarse de "la validez de la comparecencia", y acto seguido dictar resolución admitiendo el recurso. Pero, para realizar estas operaciones, es preciso que el escrito presentado por la CNMC en el Registro de la Audiencia Nacional llegue físicamente al Secretario Judicial, y que éste examine y despache, por su orden de llegada, todos los restantes documentos que ese mismo día hayan ingresado en el Registro, que pueden ser muy numerosos. Todo ello puede consumir varias jornadas de trabajo, de manera que será excepcional que el plazo perentorio establecido en el precepto antes transcrito pueda observarse. Sin duda, hubiera sido preferible hablar de "a la mayor brevedad" u otra fórmula semejante.

b) Es extraño que la Ley no haga ninguna mención a la resolución del Secretario Judicial por la que declare la admisión del recurso. Es cierto que ya se refiere a ella el artículo 45.3 de la LJCA, supletoriamente aplicable; pero una alusión explícita no hubiera sido superflua, porque en este proceso especial dicha resolución posee una importancia mayor que en el proceso ordinario, ya que, como vimos en el anterior epígrafe D.3, es el acto que determina la producción de la suspensión del acto o disposición impugnados. Como también se echa en falta una referencia a la comunicación que habrá de hacerse de tal resolución a la Administración demandada (cuya recepción determinará el comienzo efectivo de la suspensión) y a su publicación oficial, cuando el recurso se dirija contra una disposición de carácter general.

c) ¿A qué expediente administrativo se refiere la Ley, y a quién ha de reclamarse? En cuanto a lo primero, téngase en cuenta que en estos procedimientos hay dos expedientes: de una parte, el que dio lugar a la aprobación de la dispo- 
sición o acto administrativo objeto del recurso, y que deberá haber sido tramitado por la Administración demandada; de otra, el expediente que se habrá constituido en el procedimiento de la reclamación ante el Consejo para la Unidad de Mercado y, después, ante la CNMC, que regulan los artículos 26 y 27 de la LUM.

En nuestra opinión, el expediente a reclamar es el primero de los mencionados, pues es el que se refiere a la formación del acto o disposición impugnados. Pero no puede eludirse el hecho de que dicho expediente no proporcionará excesivos elementos de juicio al tribunal que conozca del recurso, porque la ilegalidad del acto o disposición impugnados derivará no de elementos intrínsecos, sino de sus efectos: cuando dicho acto o disposición produzca una lesión en la unidad de mercado; y, para valorar la existencia de tal lesión, será mucho más ilustrativo el segundo expediente antes aludido, que es donde se habrá debatido la existencia o inexistencia de una lesión a las libertades de establecimiento y circulación. Pero este segundo expediente, pese a su mayor utilidad, no es el que debe remitirse por la Administración demandada, porque tampoco se hallará en su poder, sino en el del Consejo para la Unidad de Mercado o de la CNMC; y este segundo expediente deberá ser aportado por la representación procesal de la CNMC junto con el escrito de demanda, en la medida en que dé soporte a su impugnación.

d) El expediente que la Administración demandada ha de remitir deberá ir "acompañado de los informes y datos que se soliciten en el recurso". El artículo 127 ter, 1, no da indicación alguna de a qué informes y datos quiere referirse (el artículo 48 de la LJCA no contiene una mención similar); ello parece suponer que se pretende abrir a la CNMC una posibilidad de requerir el envío de cualesquiera informaciones que fueren necesarios u oportunos para ponderar en qué medida la citada actuación puede suponer una vulneración de las libertades de establecimiento y circulación.

Esta ampliación del expediente está tomada del artículo 116.1 de la LJCA, relativo al procedimiento especial de protección de derechos fundamentales, pero con una variación relevante: en dicho procedimiento, los informes y datos que la Administración demandada haya de remitir son los que la misma "estime procedentes", mientras que en el proceso especial que examinamos en este trabajo son los que la CNMC exija en su escrito de interposición. Y la dificultad surgirá, obviamente, en el caso, harto probable, de que dichos informes y datos no obren en el expediente administrativo y que, por tanto, hayan de elaborarse ad hoc. No nos parece inadecuada esta facultad de reclamar tales informaciones; pero la posibilidad de cumplirla se da de bruces con la exigencia de que el expediente, y tales informaciones, hayan de remitirse a la Audiencia Nacional en el brevísimo plazo de cinco días, que será de muy difícil cumplimiento. 
La fijación de un plazo tan fugaz (que también está tomado del procedimiento de protección de derechos fundamentales), responde nuevamente a las prisas del legislador, que pretende imprimir al proceso un ritmo artificialmente acelerado. Pero, en este caso, tal urgencia juega justamente en contra de la pretensión de celeridad, porque i) lo normal es que el expediente no llegue a la Sala en el plazo indicado; ii) como "la falta de envío del expediente administrativo dentro del plazo previsto en el apartado anterior no suspenderá el curso de los autos" (artículo 127 ter, 2), la CNMG se verá obligada a formalizar su demanda sin tener a la vista el expediente y los informes y datos que haya solicitado; y iii) cuando tales informes y datos lleguen finalmente al órgano jurisdiccional, este deberá dar un plazo adicional de alegaciones (artículo 127 ter, 3), con lo que el tiempo "ganado" con el mínimo plazo de envío del expediente se perderá con creces con el que haya de consumir dicho plazo de alegaciones complementarias. Como se dice coloquialmente, para ese viaje no se necesitaban tales alforjas.

\section{Emplazamiento de los interesados}

De acuerdo con el artículo 48.1 de la LJCA, en el oficio en que se reclame el expediente administrativo se ordenará a la Administración demandada que practique los emplazamientos previstos en el artículo 49: esto es, a todos cuanto aparezcan interesados en el proceso.

Aunque el artículo 127 ter no hace referencia a este trámite, su obligatoriedad es evidente y no necesita ser justificada. Pero no puede ocultarse que su cumplimiento planteará, en numerosas ocasiones, dudas insolubles a la Administración demandada, habida cuenta del carácter abstracto que tendrán no pocas impugnaciones; porque incluso en los casos en los que se recurra un acto administrativo singular, la sentencia puede afectar a múltiples operadores económicos; a miles, sin hipérbole alguna.

No es fácil indicar a quién habrá de emplazarse para personarse en el recurso. Desde luego, si previamente a su interposición se hubiera seguido por alguna persona los procedimientos de reclamación regulados en los artículos 26 y 27 de la LUM, la misma deberá ser necesariamente emplazada. Pero no se puede ir más allá, porque, por las razones antes mencionadas, será prácticamente imposible adivinar qué personas físicas o jurídicas (incluso otras Administraciones) pueden tener interés en el resultado del litigio.

Por ello, creemos que hubiera sido aconsejable que el artículo 127 ter hubiera previsto algunas modalidades de difusión del litigio distintas del mero emplazamiento personal. Aun siendo consciente de su escasa eficacia en el plano de la publicidad material, no habría sido impertinente que la interposición de estos pro- 
cesos fueran objeto de la publicación oficial prevista en el artículo 47.2 de la LJCA; si bien invirtiendo la regla que el mismo establece, ya que la publicación de los recursos interpuestos contra una disposición de carácter general seria innecesaria si, como antes expusimos, se inserta en un periódico oficial la suspensión de la norma impugnada. Y, dado el alcance general que estos recursos tienen, tampoco sería desacertado que la CNMG publicitara su interposición en su página web.

\section{La acumulación y sus problemas}

El apartado 8 del artículo 127 ter dispone que "la Sala de lo Contencioso-Administrativo de la Audiencia Nacional acordará la acumulación al promovido por la Comisión Nacional de los Mercados y la Competencia de todo procedimiento que, iniciado por un operador económico ante el mismo u otro órgano jurisdiccional, se dirija frente a la misma disposición o actuación y se funde en la vulneración de la libertad de establecimiento o de circulación conforme a lo previsto en esta Ley".

Esta norma, cuya justificación no es preciso explicitar, por notoria, merece también algunos comentarios.

a) Ante todo, debe hacerse mención de la singularidad que supone este régimen de acumulación frente al previsto en el artículo 37.2 de la LJCA, del que es una aplicación concreta. Como es bien sabido, acordar la acumulación de procesos entraña una valoración del grado de conexión que existe entre sus diversos objetos; lo cual, unido a la expresión que el citado precepto utiliza (“...el órgano jurisdiccional podrá en cualquier momento procesal, [...] acordar la acumulación de oficio o a instancia de alguna de ellas [de las partes], ha llevado a la jurisprudencia a considerar esta decisión como discrecional del órgano jurisdiccional (STS de 3 de marzo de 2004, Rec. 3053/2001, con cita de jurisprudencia anterior). El apartado 8 del artículo 127 ter, por el contrario, parece imponer la acumulación con carácter obligatorio: "la Sala de lo Contencioso-Administrativo de la Audiencia Nacional acordará la acumulación...".

b) Esta obligación de acumular no afecta, sin embargo, a todos los supuestos contemplados en el artículo 37.2 citado: sólo al previsto en el apartado 1 del artículo 34, cuando las pretensiones se ejerzan "en relación con un mismo acto, disposición o actuación", y siempre que el recurso se fundamente en la vulneración de la libertad de establecimiento o de circulación.

¿Pueden, no obstante, acumularse facultativamente procesos en los que no concurran estos requisitos? En líneas generales, esta pregunta debe responderse 
negativamente. Desde luego, la acumulación parece improcedente cuando la impugnación de los mismos actos o disposiciones se base en motivos ajenos a la vulneración de la unidad de mercado: dada la estricta finalidad del proceso especial que analizamos en este trabajo, la acumulación no tendría sentido y sería disfuncional. Y lo mismo cabe decir de procesos que tengan por objeto actos o disposiciones diversas, solo relacionados por su fundamento impugnatorio: sería absurdo, por ejemplo, que estando dirigido el proceso incoado por la GNMC contra un acto por el que se impone a un operador el deber de residencia en el territorio de una comunidad autónoma (artículo 18.2.a, 2. ${ }^{\circ}$ de la LUM), se acumulase a él otro en el que lo que se impugnara fuese la negativa al reconocimiento de la autorización expedida por otra Administración pública (artículo 20.1.a de la LUM); la continencia de la causa exige una cierta homogeneidad no sólo en los motivos impugnatorios, sino también en cuanto al objeto del recurso.

En este último supuesto solo cabría, a nuestro juicio, la acumulación de procesos dirigidos contra actos entre los que existiese una relación directa: por ejemplo, que se impugnasen preceptos diversos de un mismo texto reglamentario, o un acto de aplicación del reglamento recurrido por la CNMC; o un reglamento de desarrollo de éste.

c) En cualquier caso, la acumulación de estos procesos ofrecerá dificultades considerables cuando se hayan interpuesto ante órganos distintos a la Sala de lo Contencioso-Administrativo de la Audiencia Nacional. Es evidente que dicha Sala carece de medios hábiles para conocer los recursos que, interpuestos por particulares o entidades asociativas, se tramiten ante otros órganos jurisdiccionales con el mismo fundamento de vulneración de la unidad de mercado. Pero tampoco dichos particulares y entidades asociativas disponen de medios para tener noticia de los que interponga la GNMC, salvo los que se inicien por ésta contra disposiciones generales y sean objeto de suspensión (la cual, como antes vimos, debe ser objeto de publicación en un diario oficial), o aquellos de considerable importancia de los que se hagan eco los medios de comunicación.

Es previsible, pues, que la norma del apartado 8 del artículo 127 ter tendrá un grado muy limitado de eficacia, salvo respecto de los procesos que, con idéntica fundamentación, se tramiten ante la propia Audiencia Nacional. A ello han de añadirse no solo la resistencia, muchas veces comprensible, que todos los órganos jurisdiccionales muestran a la acumulación de procesos, por la complejidad exponencial que exige su fallo conjunto, sino también la propia celeridad que los artículos que comentamos imponen a este proceso: si ya es dudosamente realista (y razonable) pretender que procesos de esta dificultad e importancia se sentencien en el plazo de cinco días (artículo 127 ter, 6), resolver en el mismo plazo cinco o seis procesos acumulados en los que habrían de valorarse motivos de im- 
pugnación distintos a la lesión de la unidad de mercado, y pretensiones diversas de reconocimiento de situaciones jurídicas individualizadas o indemnizatorias, se convierte en una fantasía de ciencia ficción.

Es muy probable que los redactores de esta norma tuvieran in mente la exclusiva acumulación, al interpuesto por la GNMC, de aquellos procesos contenciosos ordinarios emprendidos por particulares, corporaciones o asociaciones profesionales que, habiendo iniciado el trámite de reclamación ante el Consejo de Unidad de Mercado regulado en el artículo 26 de la LUM, optaran después por litigar independientemente. Dado que dichas personas se encontrarán identificadas en los documentos que la CNMC aporte con su demanda, sería preferible que se procediera a su emplazamiento y se les ofreciera intervenir en el proceso principal en la forma prevista en el artículo 127 ter, 7; requiriéndoles información acerca de los procesos separados emprendidos por ellos, a efectos de su posible acumulación.

\section{F) Fase de alegaciones y prueba}

La fase del proceso referida al debate entre las partes merece muy escasos comentarios. Su regulación en los apartados 3 a 5 del artículo 127 ter se halla, una vez más, fuertemente inspirada en la del procedimiento especial de protección de los derechos fundamentales (artículo 118 a 120 de la LJCA), de la que es un calco notorio, salvo en la ausencia de participación del Ministerio Fiscal y en la muestra de una leve generosidad al fijar la duración de los plazos para formalizar demanda y contestación (diez días en lugar de ocho).

Esto no obstante, estos apartados exigen algunas consideraciones; en este caso, claramente críticas.

a) En primer lugar, y al igual que sucede en el procedimiento tomado como modelo, se excluye la entrega del expediente a las partes para formalizar su demanda y contestación, que es sustituida por su puesta de manifiesto a los representantes de las partes en la Secretaría de la Sala. Esta opción nos parece claramente desafortunada tratándose de asuntos tan complejos y delicados, que exigirán un trabajo conjunto dentro de cada una de las Administraciones litigantes; hacerlo sobre la base de las notas manuscritas que el representante procesal pueda tomar, o de las fotocopias sueltas que pueda conseguir, y en diez días, es una incitación al desaliño. La unidad de mercado parece que exigiría una forma de actuar más reflexiva y pausada.

b) Se prevé un "trámite adicional de alegaciones a las partes" en el caso de que el expediente administrativo no haya llegado a la Sala en el plazo que impo- 
ne el apartado 1 de este artículo 127 ter; trámite que, por la extrema brevedad del plazo de envío del expediente, habrá de utilizarse en la mayoría de los casos, neutralizando la celeridad que pretende imprimirse a la tramitación del recurso con la fijación de dicho plazo, como ya advertimos anteriormente. A esta incoherencia habrá de sumarse la escasa cortesía mostrada por el legislador, que no se molestó en fijar la duración de este trámite de alegaciones: creemos que podría ser aplicable el de diez días que establece el artículo 53.2, por más que los supuestos de hecho de ambos preceptos no sean idénticos; lo que hace que la analogía resulte un tanto discutible.

c) La Ley insiste en el ridículo énfasis (que también se encuentra en los artículos 118 y 119) de calificar de "improrrogables" los plazos para formalizar la demanda y la contestación, cuando a nadie se le oculta, a estas alturas de la película, que dichos plazos pueden ser ampliados hasta el día siguiente a la fecha de notificación del auto declarando la caducidad de los respectivos trámites, como prevén los artículos 52.2 y 128.1 de la LJCA.

d) Y, asimismo, y siempre en la línea de acortar al máximo la tramitación de estos procesos, se guarda un equívoco silencio en relación con dos trámites relevantes propios del procedimiento ordinario (desde luego, con clara intención de suprimirlos): de una parte, el de alegaciones previas regulado en los artículos 58 y 59 (que quizá se suprime bajo la hipótesis de la breve duración teórica del proceso, que permitiría decidir sobre las causas de inadmisibilidad directamente en la sentencia); y, de otra, el de vista o conclusiones, sobre el que también guardan silencio los artículos relativos al procedimiento de protección de los derechos fundamentales y que, por tanto, ha de entenderse excluido de este proceso especial; sin ningún fundamento sólido, ya que una segunda ocasión para alegar puede ser más que aconsejable en asuntos que normalmente revestirán una seria complicación y en los que la prueba poseerá una relevancia considerable.

\section{G) Terminación del proceso}

\section{La sentencia y su contenido}

El apartado 6 del artículo 127 ter se refiere a la sentencia con la que ha de concluir este proceso, en una discutible copia literal de los apartados 1 y 2 del artículo 121 de la LJCA, también referidos al procedimiento de protección de los derechos fundamentales. Con él se hace bueno el dicho de que no hay un mal modelo que no pueda ser empeorado por una copia. En efecto:

a) Se toma del artículo 121.1 el absurdo plazo de cinco días para dictar sentencia. A ello ya nos hemos referido anteriormente en diversas ocasiones, por lo 
que, por respeto al legislador, no añadiremos más: una norma condenada al desuso desde su primer día de vigencia.

b) Se reproduce el mismo defecto en que incurre el artículo 121.2 de no referirse más que a uno de los posibles pronunciamientos de la sentencia, como si no cupiera otro distinto del de estimación del recurso.

Es cierto que la finalidad de esta mención (que podría haberse sustituido con ventaja por una referencia a lo dispuesto en los artículos 68 a 73 de la LJCA) radica en la exigencia, para que el fallo estimatorio pueda pronunciarse, de que la infracción del ordenamiento jurídico "afecte a la libertad de establecimiento o de circulación". Pero dicha puntualización es tan ociosa como la que el artículo 121.2 hace a que la infracción del ordenamiento debe suponer la vulneración de un derecho constitucional susceptible de amparo, porque la exigencia está implícita en la propia existencia de este proceso especial: un recurso que solo puede interponerse cuando se estime que una actuación administrativa "sea contraria a la libertad de establecimiento o de circulación en los términos previstos en la Ley 20/2013, de Garantía de la Unidad de Mercado" (artículo 127 bis 1), es evidente que no puede estimarse por el tribunal más que cuando se aprecie la efectiva existencia de una infracción que afecte a estas libertades. En resumen: una obviedad.

c) No es obvia ni irrelevante, por el contrario, la precisión que se hace de que la sentencia, además de corregir la conducta infractora (a lo que nos referiremos en el epígrafe siguiente) se pronunciará sobre "el resarcimiento de los daños y perjuicios, incluido el lucro cesante, que dicha conducta haya causado".

En primer lugar, la sentencia podrá también reconocer una situación jurídica individualizada (artículo 71.1.b LJCA) en el caso de participación en el proceso de un tercero interviniente (artículo 127 ter, 7), a favor del mismo y siempre que lo haya solicitado; no es justificable el silencio sobre este punto, que podría apoyar una interpretación (errónea) a contrario sensu, en el sentido de que la sentencia que se dicte en este proceso especial no podría declarar tal reconocimiento, al no haberlo mencionado.

Y, en segundo lugar, es ociosa y comprometida la precisión de que el pronunciamiento de indemnización de daños y perjuicios incluye el lucro cesante, al que el artículo 71.1.d) no alude: es ociosa porque el deber indemnizatorio incluye, por definición, la compensación tanto del daño emergente como del lucro cesante (por más que la jurisprudencia le haya impuesto mil limitaciones); y es comprometida, porque su inclusión en este artículo podría avalar, nuevamente, una interpretación sistemática a contrario sensu del citado artículo 71.1.d): si el artículo 
127 ter menciona expresamente la indemnizabilidad del lucro cesante, podría pensarse que dicho concepto no debe entenderse compensable en los restantes preceptos de la LJCA que se refieren, genéricamente, a la indemnización de daños y perjuicios.

d) Y mucho más sorprendente aún, por fin, es la indescriptible prevención contenida en el párrafo segundo del citado apartado 6 del artículo 127 ter, según la cual "conforme a lo dispuesto en el artículo 71, la sentencia que estime el recurso implicará la corrección de la conducta infractora".

Veamos: primero, el artículo 71 de la LJCA no habla en ningún momento de la "corrección", sino de anulación total o parcial; segundo, lo que "corrige" o anula la sentencia no es ninguna "conducta infractora", sino un acto administrativo o una disposición de rango inferior a la ley; tercero, que la infracción no es cometida por ninguna "conducta", sino por el resultado de la misma, que son el acto o disposición recurridos; y cuarto, último y principal, que, si esta surrealista expresión no es producto de un lapsus calami, hubiera sido muy positivo y conveniente que se explicara a los aplicadores de la ley qué significa que la sentencie "implique" la "corrección de la conducta infractora". Un recurso contencioso no puede perseguir otra finalidad que la anulación del acto o disposición impugnados, y dicha anulación producirá los efectos inherentes a la misma: prohibición de ejecutar el acto o aplicar en lo sucesivo la disposición anulada, al privarles de su validez; evidentemente, lo que la sentencia no puede imponer a la Administración demandada es la prohibición de dictar en lo sucesivo un acto o disposición iguales o equivalentes, ni amonestarle (que es uno de los sinónimos de "corregirle") por haber ocasionado un atentado ilegítimo a la unidad de mercado.

El mejor destino que cabe a los dos primeros párrafos del apartado 6 del artículo que comentamos es su más completo olvido.

\section{La forma de la sentencia y las sentencias in voce}

Hasta el primer párrafo del apartado 6, el artículo 127 ter se limita a efectuar una mala copia de los preceptos reguladores del procedimiento especial para la protección de los derechos fundamentales de la persona. En el segundo, en cambio, se lanza con osadía a la innovación normativa, con los resultados que acabamos de exponer; y en los siguientes párrafos del apartado insiste en la misma línea creativa, alumbrando una nueva genialidad de la ingeniería procesal: las sentencias pronunciadas in voce.

a) No es necesario recordar que esta forma de dictar las sentencias carece de precedentes en el sistema español de justicia administrativa, y que la LJCA no las 
admite en supuestos que podrían estar justificados: no lo hace en la vistilla prevista en el artículo 135.1.a) para la confirmación o levantamiento de la medida cautelar adoptada inaudita altera parte, ni tampoco en el procedimiento abreviado (artículo 78.20), en el que quizá podría emplearse para resolver litigios sencillos y repetitivos (por ejemplo, multas de tráfico, expulsiones de extranjeros e inadmisión de peticiones de asilo; y no en todos los casos).

Pero es dificil imaginar un tipo de procesos en los que esta forma de dictar sentencia sea menos adecuada.

Hemos recordado reiteradamente que los procesos en garantía de la unidad de mercado serán, normalmente, de una importante complejidad; no solo jurídica, sino sobre todo económica, porque apreciar que una determinada actuación administrativa produce, o no, una lesión de las libertades de establecimiento o circulación exigirá un razonamiento detallista y muy matizado. Serán, también, de una notable delicadeza, porque lo que se resolverá en todos los casos será, en definitiva, un conflicto entre la norma estatal y las disposiciones o actos que las Comunidades Autónomas o las entidades locales hayan dictado en ejercicio de sus competencias. Para confirmar estas apreciaciones no cabe mejor ejercicio que la lectura de las sentencias del Tribunal de Justicia de la Unión Europea dedicadas, igualmente, a enjuiciar las medidas lesivas de estas dos libertades por cada uno de los Estados miembros.

Pretender sustituir una sentencia escrita por una exposición oral improvisada sobre temas tan complejos y delicados es, dicho sin ambages, una insensatez que ningún miembro de la carrera judicial osará cometer, supongo, salvo apoyándose en un texto escrito que haya elaborado cuidadosamente (en cuyo caso, lo preferible sería convertirlo en una sentencia ordinaria). Porque cualquier sentencia que se dicte en esta materia (sobre todo si es estimatoria) entrañará una censura implícita muy seria a la Administración demandada: no solo por imputarle una vulneración de lo dispuesto en el artículo 139.2 de la Constitución, sino porque dicha infracción atenta a dos de las libertades básicas sobre las que se asienta todo el edificio europeo; y será objeto de críticas aceradas y de imputaciones solapadas de centralismo (o de autonomismo desaforado).

b) Pero no se trata solo de la inadecuación de las sentencias in voce al objeto de este proceso especial. En el desarrollo que el propio apartado 6 hace de esta peculiar forma de sentenciar encontramos algunas otras prevenciones que merecen un breve comentario; por desgracia, nada favorable.

En primer lugar, el detalle del contenido de la exposición oral de la sentencia. El magistrado encargado de la misma (¿el ponente?) deberá relatar "los razona- 
mientos en que sustente su decisión, resolviendo sobre los motivos que fundamenten el recurso y la oposición y pronunciando su fallo". Aparte de que los razonamientos de la decisión y la valoración de los motivos del recurso y la oposición son una y la misma cosa, formulemos dos preguntas: ¿la sentencia no ha de hacer alusión alguna a los antecedentes de hecho? Y los contenidos que este precepto menciona, ¿no son los que enumera el artículo 209 de la Ley de Enjuiciamiento Civil? ¿Para qué repetirlos (con omisiones) entonces?

Y, en segundo lugar, la prescripción del párrafo cuarto, según la cual "la no comparecencia de todas o alguna de las partes no impedirá el dictado de la sentencia de viva voz". Es evidente que una sentencia debe poder dictarse, se hallen o no presentes las partes. Pero ¿podría explicársenos qué finalidad tiene una sentencia dictada de viva voz ante un auditorio vacío? ¿Acaso se obliga a algún profesor a dictar una clase estando el aula sin un solo alumno? ¿Qué oscura finalidad pretende someter a los miembros de la Sala a una situación tan absurda y desairada?

c) En estas condiciones, no sería extraño que la aplicación de esta peculiar modalidad de dictar sentencias quede inédita. Y muy probablemente será así, paradójicamente, por la propia regulación que el artículo 127 ter, 6 hace de la misma.

En efecto. Dicho precepto admite el pronunciamiento de las sentencias in voce solo "cuando se trate de asuntos en los que no quepa ulterior recurso" contra las mismas; recurso que será el de casación, único que procede contra las sentencias dictadas por la Sala de la Audiencia Nacional en única instancia (artículo 86.1 de la LJCA). Y resulta que, dada la configuración que se da a este recurso, su admisión procederá en todos los casos, ya que i) las impugnaciones que haga la CNMC de actuaciones contrarias a la unidad de mercado serán siempre de cuantía indeterminada, no siéndoles de aplicación el umbral establecido en el artículo 86.2.b) de la LJCA, y ii) las sentencias no podrán versar sobre cuestiones de personal, ni sobre las dos restantes excepciones establecidas en las letras c) y d) del mismo artículo y apartado.

Por fortuna, el propio legislador ha puesto remedio al dislate que supone esta exótica modalidad de sentenciar.

\section{La extensión de efectos de la sentencia}

Además de los nuevos preceptos de la LJCA que hemos venido analizando en las páginas precedentes, la disposición final primera de la LUM introduce una modificación en el apartado 1 del artículo 110 de aquélla: una modificación for- 
malmente muy leve, consistente en la adición, a la relación inicial de materias cuyas sentencias son susceptibles de extensión de efectos ("En materia tributaria y de personal al servicio de la Administración pública..."), el inciso "y de unidad de mercado".

a) En la primera lectura que se hace de la LUM, esta reforma suscita una cierta extrañeza: no se entiende bien cómo puedan ser susceptibles de extensión de efectos las sentencias dictadas en un recurso institucional (en cuanto exclusivamente emprendido por un organismo público estatal) y cuya finalidad no es el reconocimiento de situaciones jurídicas individualizadas, sino un pronunciamiento abstracto de restauración del orden jurídico, dirigido a la anulación de actuaciones administrativas que lesionen las libertades constitucionales de establecimiento y circulación.

b) La explicación de esta aparente incongruencia se encuentra, claro está, en la facultad que se reconoce a "cualquier operador económico que tuviere interés directo en la anulación del acto, actuación o disposición impugnada" para personarse en el proceso y participar en él como parte recurrente.

Como ya señalamos con anterioridad (véase el epígrafe IV.B.3 de este trabajo), estos terceros intervinientes pueden formular en el proceso pretensiones distintas de la anulación, consistentes en el reconocimiento de situaciones jurídicas individualizadas. El artículo 127 ter sólo habla de pretensiones de resarcimiento de daños y perjuicios; pero, en la medida en que dichas pretensiones no son más que una de las posibles de restablecimiento de la situación jurídica individualizada (vid. artículo 31.2 de la LJCA), parece evidente que dichos intervinientes también podrán pretender la declaración de ésta. Y son estas situaciones individualizadas que la sentencia puede declarar las que pueden ser reconocidas, en el incidente del artículo 110 de la LJCA, a quienes, encontrándose en idéntica situación jurídica que los favorecidos por el fallo, lo soliciten en la forma establecida por dicha norma.

c) Esta explicación choca, sin embargo, con el obstáculo de la regla contenida en la letra b) del citado artículo 110.1, según la cual el órgano jurisdiccional que dictó la sentencia cuya extensión se pretende debe ser "también competente, por razón del territorio, para conocer de sus pretensiones de reconocimiento de dicha situación individualizada"; regla que puede resultar incompatible con la atribución exclusiva de competencia que el artículo 11.1.h) de la LJCA hace a favor de la Sala de lo Contencioso-Administrativo de la Audiencia Nacional.

Expliquémoslo con un ejemplo. Supongamos que una ordenanza municipal exige una autorización específica para el ejercicio, en su término, de una deter- 
minada actividad económica, y que rechaza la validez de las otorgadas con la misma finalidad por otros Ayuntamientos (contra lo que establece el artículo 20.1.a) de la LUM), imponiendo multas a los empresarios que realizan dicha actividad careciendo de dicha autorización específica. Supongamos también que la CNMC impugna dicha ordenanza, y que se persona en el proceso uno de los industriales sancionados, solicitando al tribunal que se reconozca su derecho a ejercer la actividad y que se anule la sanción que se le hubiere impuesto; y la $\mathrm{Au}-$ diencia Nacional anula efectivamente la ordenanza y reconoce las pretensiones ejercidas por el industrial interviniente.

¿Qué podrán hacer los restantes empresarios a los que se ha impedido el ejercicio de la actividad? Dado que la actividad administrativa lesiva proviene de un Ayuntamiento, el órgano jurisdiccional competente para conocer de los recursos contra la misma será, normalmente, el Juzgado de lo Contencioso-Administrativo; pero la sentencia cuya extensión de efectos se quiere solicitar ha sido dictada por la Audiencia Nacional, la cual habría de rechazar la solicitud de extensión por carecer de competencia para reconocer la misma situación jurídica individualizada.

Este conflicto, originado por la atipicidad de la atribución competencial hecha por el artículo 11.1.h) de la LJCA a favor de la Audiencia Nacional, que hace abstracción de la autoridad o Administración que realiza la actuación lesiva de la unidad de mercado, es, a nuestro juicio, meramente aparente: los industriales que pretenden la extensión de efectos podrían haberse personado en el proceso incoado por la GNMC; y, de haberlo hecho, la Audiencia Nacional resultaría competente para acoger sus pretensiones individualizadas, por lo que debe entenderse que ostenta también competencia para reconocérselas en un incidente de extensión de efectos de su sentencia.

d) Esta vía de extensión de efectos, sin embargo, no es solo aplicable a las sentencias que la Audiencia Nacional dicte en procesos incoados por la CNMC: recordemos que los particulares pueden también ejercer acciones en defensa de sus intereses, con fundamento en la vulneración de la unidad de mercado, en otros procesos ordinarios, completamente ajenos a los institucionales emprendidos por la GNMC; y que pueden hacerlo incluso en el supuesto de que hayan formulado reclamaciones ante el Consejo para la Unidad de Mercado (o peticiones a la CNMC), apartándose en cualquier momento de la continuación de dicha vía (véase el epígrafe III.C de este trabajo). Parece evidente que las sentencias estimatorias que se dicten en los referidos procesos podrán también ser objeto de extensión, ya que la mención que el artículo 110.1 de la LJCA hace a la unidad de mercado no limita las sentencias susceptibles de extensión a las dictadas en los procesos especiales tramitados al amparo de los artículos 127 bis, ter y quáter; bas- 
tando con que la estimación del recurso se base en la infracción de las libertades de establecimiento o circulación.

\section{UNA VALORACIÓN DE CONJUNTO}

El análisis de la nueva vía procesal introducida por la LUM no puede limitarse a la exposición y disección de los textos legales en los que se plasma. Esta exposición, además de resultar lamentablemente árida y pragmática (y soy el primero en percibirlo) quedaría incompleta sin intentar una valoración de conjunto, contemplando la construcción legal desde una perspectiva global.

1. No tengo la información suficiente, ni las ideas lo bastante claras como para concluir si la reforma era necesaria. Hay, no obstante, algunas evidencias que es oportuno recordar.

Que la evolución del Estado autonómico ha producido una fuerte disparidad normativa es un hecho notorio, como también lo es que esta disparidad se va intensificando con el paso del tiempo: muchos de los textos legales que las Comunidades Autónomas aprobaron en los quince primeros años de funcionamiento de sus instituciones se asemejaban notablemente a las normas estatales que venían a desplazar (y también entre sí: la copia descarada de unos textos por otros fue una pauta de conducta muy generalizada); pero los que han venido a sustituir a los primeros se apartan más y más de aquellos modelos, y la cómoda copia ha sido reemplazada por la creatividad desbordante de los juristas locales.

Asimismo, es un hecho evidente que esta disparidad normativa ha ido creando obstáculos progresivos al ejercicio de las libertades de establecimiento y circulación, que han afectado mucho más a la primera que a la segunda, y que ha generado costes crecientes de gestión a los operadores económicos. Para cualquier empresa de ámbito no estrictamente local, tener que operar con sujeción diecisiete ordenamientos distintos es una auténtica tortura, como sabemos a la perfección todos los abogados que nos dedicamos a su asesoramiento.

Y la tercera evidencia: la disparidad normativa ha venido amparada, cuando no fomentada, por una jurisprudencia constitucional complaciente, que no solo la ha bendecido como una consecuencia inexorable (e incluso positiva) del principio de autonomía política, sino que ha eludido conscientemente todo intento de frenar tal disparidad aplicando el claro imperativo establecido en el artículo 139.2 de la Constitución.

La pretensión de frenar legislativamente este paulatino deterioro, antes de que 
adquiera mayor gravedad y se torne dificilmente reversible parece, en principio y dicho con todas las reservas, bastante plausible.

2. Cuestión distinta es si resulta acertado confiar la consecución de este objetivo a un sistema de acciones judiciales; extremo este sobre el que albergo muy serias dudas.

Es verdad que la Constitución prevé (artículo 153) un régimen prioritario de control jurisdiccional del Estado sobre la actividad de las Comunidades Autónomas, y que la Ley Reguladora de las Bases del Régimen Local ha optado también por esta línea respecto del control de los Ayuntamientos y Diputaciones. Pero, de una parte, me parece que la unidad de mercado no es un objetivo que pueda conseguirse y mantenerse a golpe de impugnación y de sentencia; y, de otra, que existen técnicas mucho más eficaces para corregir las disfunciones de la disparidad normativa y constitucionalmente pensadas para ello. Me refiero, claro está, a las leyes de armonización, absurdamente demonizadas entre nosotros desde el desafortunado intento de la LOAPA y condenadas a la inutilidad desde la inefable STC 76/1983; probablemente, la peor de las sentencias que el Tribunal Constitucional ha pronunciado desde su creación, y la de consecuencias más graves. $\mathrm{Me}$ sumo a otras muchas opiniones que han propugnado su urgente recuperación, compartiendo su desconfianza desalentada de que ello pueda ser posible.

3. Pero, puestos a no utilizar más medidas correctoras que las impugnaciones judiciales, ¿es suficiente y adecuado el diseño que la LUM ha hecho de ellas?

Hay en él aspectos claramente positivos, como la exclusividad de la competencia de la Audiencia Nacional para conocer de estos litigios, o el régimen de suspensión automática de las actuaciones recurridas, aunque la actitud conciliadora y la excesiva moderación que los sucesivos gobiernos del Estado han mostrado hacia la imparable dinámica autonómica han propiciado la incorporación al texto de la Ley de reglas que pueden debilitar o neutralizar tales avances: me refiero a la dispersión competencial del conocimiento de los recursos ordinarios que los particulares planteen al margen de los procedimientos establecidos en la LUM, o la posibilidad de un levantamiento casi inmediato de la suspensión que estos recursos producen.

¿Ha sido acertada la decisión de confiar la legitimación exclusiva para el planteamiento de estos recursos a la CNMC? Desearía equivocarme, pero me temo que no. En primer lugar, como operación de imagen, es fútil pensar que encomendar la iniciativa de estos recursos a un organismo público independiente va a despolitizar estos procesos: toda impugnación que se realice será denunciada, desde la perspectiva territorial, como una agresión a la respectiva autonomía, re- 
alizada por un ente al que se presentará como el brazo armado del Gobierno (nada independiente, por supuesto).

Pero, además, tengo el temor de que la encomienda que la LUM hace a la CNMG sea superior a sus capacidades reales de actuación, por la multitud y dureza de las tareas que se le han atribuido. El nuevo superregulador ha acumulado en su haber una plétora de responsabilidades, todas ellas muy diferentes entre sí y de una considerable trascendencia: la de control de las actuaciones lesivas de la unidad de mercado constituye una novedad cualitativa más, que corre el riesgo de diluirse y de quedar relegada a un segundo plano frente a otras múltiples. Bastante tiene la GNMC con tener que enfrentarse a las más poderosas empresas del país en los asuntos de competencia, de supervisión del mercado eléctrico y del de telecomunicaciones, entre otros sectores no menos conflictivos y poderosos, como para echarle ahora a pelear con todas las Administraciones Públicas territoriales, asilvestradas después de tres décadas de exaltación de la diversidad identitaria y de la autonomía radical.

Desearía sinceramente equivocarme al enunciar estos riesgos; pero no creo inoportuno ponerlos de relieve.

4. Y, por fin, está la cuestión de la técnica jurídica empleada en el diseño de este proceso; que, como hemos señalado al analizar muchos de sus puntos es, como mínimo, manifiestamente mejorable.

De una parte, la LUM es extraordinariamente confusa en muchas de sus regulaciones, como sucede con los procedimientos administrativos previos de sus artículos 26 y 27 y la legitimación que se concede para plantear denuncias ante el Consejo para la Unidad de Mercado y la CNMG.

Y, de otra, la reglamentación del procedimiento contencioso que se hace en los nuevos artículos 127 bis a quáter es deplorable: además de tomar como modelo un procedimiento cuya finalidad nada tiene que ver con la protección de la unidad de mercado, como el de derechos fundamentales (que tampoco pasará a la historia como un ejemplo de técnica legislativa), es claramente desaconsejable la imposible celeridad que pretende imprimirse a su tramitación; es lamentable su asimetría, que omite la regulación de cuestiones fundamentales (que crearán dudas continuas en su aplicación), pero que, en contraste, se detiene en aspectos nimios que a nadie interesan, (¿iera tan importante, por ejemplo, regular el destino del soporte videográfico de las sesiones del tribunal en las que se dicten las sentencias in voce?: artículo 127 ter, 6, párrafo final); y es desconcertante y alarmante la improvisación de originalidades patentemente inadecuadas, como sucede con las mencionadas sentencias in voce (que el propio texto de la Ley, feliz y 
paradójicamente, luego inutiliza). Sin ironía alguna, estoy convencido de que los autores físicos de estas redacciones poseen un alto nivel de competencia; y, como buen conocedor de la dificultad de redactar textos normativos, todos mis sinceros respetos a su trabajo. Pero no puedo dejar de constatar que, cuando nos sentamos ante el ordenador, todos tenemos días mucho más desafortunados que otros.

Aunque estos fallos de técnica legislativa quizá sean lo menos importante en una Ley de intenciones tan capitales para la economía del país, es nuestra obligación de juristas ponerlos de manifiesto; y, también, formular por enésima vez una súplica dirigida a la moderación en las reformas de nuestros textos legales fundamentales. La Ley de lo Contencioso fue, desde hace más de medio siglo, una de las joyas de nuestro ordenamiento jurídico, que el restyling que sufrió en 1998 no empeoró sustancialmente; pero las reformas que posteriormente ha experimentado han sido desacertadas y, lo que es peor, en su inmensa mayoría innecesarias. Las leyes no son documentos triviales donde los políticos de turno puedan verter alegremente sus neuras ni sus ocurrencias arbitristas de duermevela, sino instrumentos de trabajo delicados, con los que muchos nos ganamos la vida y en los que muchos ciudadanos siguen confiando cándidamente. Pedir un poco de respeto, de debate y de sentido de responsabilidad a la hora de pensar en su modificación no parece nada descomedido. 